\title{
Kroniek rechtspraak rechten van de mens
}

\author{
Prof. mr. A.C. Hendriks ${ }^{*}$
}

\section{Inleiding}

Het in Straatsburg gevestigde Europees Hof voor de Rechten van de Mens (EHRM of Hof) heeft in de periode januari 2017 tot en met augustus 2018 een groot aantal uitspraken en ontvankelijkheidsbeslissingen gedaan dat van belang is voor gezondheidsjuristen. Zoals vaker het geval is, hebben de meeste van deze zaken betrekking op het recht op leven (art. 2 EVRM), het verbod van onmenselijke behandeling (art. 3 EVRM) en het recht op privé-, familieen gezinsleven (art. 8 EVRM). De oogst van deze verslagperiode omvat interessante uitspraken over het recht op patiëntveiligheid, het optreden van de autoriteiten jegens psychiatrische patiënten, het recht op cannabis en het voortzetten van levensverlengend handelen in situaties waarin artsen dat niet langer zinvol achten. Ook zijn er diverse uitspraken over het recht op schadevergoeding na een medische fout, de omgang met medische persoonsgegevens en het waarborgen van toegang tot adequate medische zorg. Hoewel geen van de in deze kroniek aangehaalde uitspraken betrekking heeft op Nederland, zijn alle uitspraken ook voor ons land van belang - al is het maar vanwege de speciale status van het EVRM in onze rechtsorde.

Ondanks de omstandigheid dat er in 2017 19\% meer klachten zijn ingediend bij het Hof dan in 2016 (63.350 tegenover 53.400), is het Hof erin geslaagd de immense werkvoorraad enigszins terug te brengen. Eind 2017 was het aantal zaken dat wachtte op afhandeling door het Hof 56.250. Roemenië (17,6\%), Rusland (13,8\%), Turkije (13,3\%) en Oekraïne $(12,6 \%)$ waren de landen van waaruit de meeste

* Aart Hendriks is hoogleraar gezondheidsrecht aan de Universiteit Leiden. klachten het Hof bereikten. Halverwege 2018 was dit aantal nog iets afgenomen tot 54.350, terwijl klagers vanuit de vier genoemde landen onverkort voor meer dan $60 \%$ van de bij het Hof ingediende klachten bleven zorgen.

Per 1 augustus 2018 is ook Protocol 16 bij het EVRM in werking getreden. Op grond van dit uit 2013 stammende protocol krijgen de hoogste hoven en tribunalen van de verdragsluitende partijen de bevoegdheid het Hof te verzoeken om advies over principekwesties die betrekking hebben op de interpretatie of toepassing van de rechten in het EVRM en de bijbehorende protocollen. Dit stelsel moet de interactie tussen het Hof en de nationale autoriteiten versterken en de tenuitvoerlegging van het EVRM in de nationale rechtsordes verbeteren. Anders dan het geval is bij prejudiciële vragen bij het Hof van Justitie van de Europese Unie is het stellen van dergelijke adviesvragen onder Protocol 16 geen verplichting voor de hoogste hoven en tribunalen.

\section{Analyse en commentaar}

\subsection{Recht op leven (art. 2 EVRM)}

Artikel 2 EVRM bevat voor de nationale autoriteiten zowel materiële als procedurele verplichtingen. Naast de materiële verplichting om zich naar vermogen in te spannen om te voorkomen dat mensen vroegtijdig komen te overlijden, zijn de nationale autoriteiten op grond van dit recht gehouden aan de procedurele plicht om sterfgevallen zorgvuldig te onderzoeken. Wie denkt dat de nationale autoriteiten op grond van deze materiële plicht zich enkel moeten onthouden (negatieve verplichting) van het - in de woorden van artikel 2 - 'opzettelijk doden van personen' heeft het mis. De nationale autoriteiten moeten zich ook inspannen (positieve verplichting) om 
te voorkomen dat mensen vroegtijdig komen te overlijden, onder andere door waarborgen te scheppen voor de patiëntveiligheid, de toegang tot medische zorg en gepast optreden van de politie bij de aanhouding van psychiatrische patiënten.

\section{- Patiëntveiligheid}

In de Georgische zaak Sarishvili-Bolkvadze 1 onderstreept het Hof het belang van patiëntveiligheid. De eisen die liggen besloten in dit begrip moeten niet slechts theoretische betekenis hebben, maar de nationale autoriteiten moeten zo nodig ingrijpen als niet aan deze eisen is voldaan.

De zaak Sarishvili-Bolkvadze was aangespannen door Gulnara Sarishvili-Bolkvadze. Dit naar aanleiding van de dood van haar zoon, G.B. G.B. was gewond geraakt nadat hij van een kraan was gevallen in februari 2004. Hij was overgebracht naar de afdeling intensive care van het ziekenhuis met een gebroken schedel en hersenschade, en werd later behandeld vanwege een maagbloeding. In maart 2004 werd hij overgebracht naar een algemene afdeling in het ziekenhuis. Nadat hij daar last kreeg van een ontsteking overleed hij op 14 maart 2004. De autoriteiten startten een strafrechtelijk onderzoek en in juni 2004 concludeerde een deskundigencommissie dat er een fout was gemaakt bij de behandeling van G.B. Het strafrechtelijk onderzoek werd vervolgens gesloten, heropend en opnieuw gesloten. Klaagster gaf geen toestemming voor een autopsie, terwijl de openbaar aanklager conform de deskundigencommissie geen causaal verband kon leggen tussen de medische fout en het overlijden van G.B. Ondertussen ontsloeg het ziekenhuis de betrokken neurochirurg en werden twee betrokken intensivisten gewaarschuwd.

Klaagster startte naast een strafrechtelijke ook een civiele procedure tegen het ziekenhuis, de medische staf en het ministerie van Arbeid, Gezondheid en Sociale Zaken wegens medische nalatigheid. De nationale gerechten oordeelden met de deskundigencommissie dat er een medische fout had plaats- gevonden, dat sommige betrokken artsen niet beschikten over de vereiste vergunningen en dat het ziekenhuis bepaalde handelingen had verricht waarvoor geen toelating was gegeven. Het Constitutionele Hof kende klaagster, in mei 2008, uiteindelijk $€ 2.700$ toe wegens materiële schade; klaagsters claim om immateriële schadevergoeding werd afgewezen.

Het Hof benadrukte zijn rechtspraak aangaande de verantwoordelijkheid van de autoriteiten bij zaken over medische nalatigheid. De autoriteiten zijn verplicht om te zorgen voor een gepast juridisch kader om de patiëntveiligheid te waarborgen, inclusief adequate waarborgen om de professionele standaard te kunnen naleven. De autoriteiten zijn daarnaast verplicht te garanderen dat het juridisch kader effectief werkt, inclusief het toezicht op en de naleving van de regels. Het Hof herhaalt dan dat de nationale rechter heeft geconstateerd dat niet alle betrokken artsen beschikten over de vereiste vergunningen en het ziekenhuis evenmin in het bezit was van een toelating die - met betrekking tot G.B.betrekking had op onder andere cardiologie en transfusies. De autoriteiten hadden deze onregelmatigheden erkend, maar hadden daarvoor geen verklaring gegeven. Het Hof merkt hierover op dat het gebrek aan noodzakelijke vergunningen in scherp contrast stond met de in Georgië geldende eisen aangaande patiëntveiligheid. Het Hof oordeelt daarom dat Georgië zijn positieve verplichtingen volgend uit artikel 2 EVRM niet had nageleefd. De civiele procedure stelde klaagster evenmin in de gelegenheid om immateriële schadevergoeding te verkrijgen. Het Hof kent klaagster geen schadevergoeding toe, omdat zij daarom niet had verzocht en onder verwijzing naar de omstandigheid dat een slachtoffer van een mensenrechtenschending een nieuwe juridische procedure kan aanvangen in Georgië. Dat laatste is in dit geval wel wat zuur, nu klaagster tien jaar na indiening van haar klacht bij het Hof formeel in het gelijk wordt gesteld, maar opnieuw moet procederen op nationaal niveau om schadevergoeding te kunnen krijgen. 


\section{- Adequate medische zorg}

Vanouds worden er jaarlijks veel zaken bij het Hof aanhangig gemaakt waarin wordt gesteld dat de autoriteiten hadden nagelaten toegang tot adequate medische zorg te bieden, in het bijzonder in situaties waarin personen van hun vrijheid zijn beroofd. Het gebrek aan adequate zorg kan het overlijden van personen tot gevolg hebben. De nabestaanden beroepen zich dan bij procedures op artikel 2 EVRM. Ook dit jaar blijkt dat de nationale autoriteiten de naleving van deze verplichting niet altijd nakomen met gevaren voor het recht op leven.

In de zaak Karakhanyan, ${ }^{2}$ afkomstig uit Rusland, stelt klaagster, mevrouw Karakhanyan, zich op het standpunt dat haar echtgenoot in 2010 in detentie was komen te overlijden als gevolg van een gebrek aan adequate medische zorg. De autopsie wees uit dat de heer Grabarchuk, de echtgenoot van klaagster, was komen te overlijden aan de gevolgen van HIV en tuberculose. De heer Grabarchuk was na zijn arrestatie gediagnosticeerd als HIV-geïnfecteerd en zes jaar later was bij hem de diagnose tuberculose gesteld. Hij was vanuit de gevangenis vervolgens overgebracht naar het gevangenishospitaal voor behandeling. Volgens het door de regering overgelegde medisch dossier, dat niet door de heer Grabarchuk was ondertekend, was de tuberculosebehandeling in het jaar dat de heer Grabarchuk was komen te overlijden gedurende een maand gestopt. De antivirale behandeling was tot aan zijn dood beëindigd. Volgens de autoriteiten was dit gebeurd op verzoek van de heer Grabarchuk. Volgens klaagster had haar echtgenoot, die tijdens detentie verkeerd was gediagnosticeerd, het vertrouwen in zijn behandelend artsen verloren en daarom bepaalde aanbevelingen naast zich neergelegd. Hij zou volgens haar aanhoudend hebben verzocht om de HIV-behandeling aan te passen in plaats van te stoppen. Ondanks pogingen van klaagster om hem over te brengen naar een burgerziekenhuis, was de heer Grabarchuk daarop in het gevangenishospitaal komen te overlijden. Vervolgens startten de autoriteiten een strafrechte-

2 EHRM 14 februari 2017, Karakhanyan t. Rusland, nr. 24421/11, ECLI:CE:ECHR:2017:0214JUD002442111. lijk vooronderzoek, in het kader waarvan zij kennisnamen van het autopsieonderzoek en twee behandelend artsen hoorden. De autoriteiten zien daarop geen reden de zaak aan de strafrechter voor te leggen. De nationale rechter gaat aan dit besluit voorbij en oordeelt dat de onderzoekers ten onrechte geen aandacht hadden besteed aan de klacht van klaagster dat er geen aandacht was besteed aan de gezondheidsstatus van haar man. Ondanks het rechterlijk bevel een vervolgonderzoek te starten, vindt dit sindsdien niet plaats.

Het Hof constateert in deze zaak een tweevoudige schending van artikel 2 EVRM. Het Hof heeft allereerst ernstige twiffels over de wijze waarop de Russische autoriteiten het recht op leven van de echtgenoot van klaagster hebben beschermd. Het Hof overweegt in dit kader dat de betreffende passages in het medisch dossier niet door de echtgenoot zijn ondertekend, terwijl klaagster zich op het standpunt stelt dat haar man persisteerde in het ondergaan van een andere behandeling in plaats van het afwijzen van een behandeling. Het Hof merkt in dit verband op dat een patiënt alleen op een betekenisvolle en intelligente wijze gebruik kan maken van zijn recht om een behandeling te weigeren nadat hij voldoende informatie heeft gekregen over de gevolgen die het weigeren met zich brengt. Dat dergelijke informatie was verstrekt, was niet gebleken. Dat leidt tot een materiële schending van artikel 2 EVRM. Deze bepaling was ook in procedureel opzicht geschonden, aldus het Hof. De autoriteiten hadden geen verslag overgelegd over het strafrechtelijk onderzoek en hadden geen verklaring gegeven voor het feit dat het onderzoekdossier inmiddels was vernietigd. Het Hof kent klaagster vervolgens bijna $€ 125.000$ aan immateriële schadevergoeding toe.

In de Portugese zaak Fernandes de Oliveira ${ }^{3}$ stelt klaagster, een moeder, dat haar zoon zich had kunnen suïcideren als gevolg van een gebrek aan goede zorg

3 EHRM 28 maart 2017, Fernandes de Oliveira t. Portugal, nr. $\quad 78103 / 14, \quad$ ECLI:CE:ECHR: 2017:0328JUD007810314, GJ 2017/90, m.nt. A.C. Hendriks. 
door een psychiatrisch ziekenhuis. De zoon van mevrouw Fernandes de Oliveira was bekend met psychiatrische problematiek en met alcohol- en middelenmisbruik. In de periode 1984-1999 verbleef hij verschillende malen op vrijwillige basis in het psychiatrisch ziekenhuis van Coimbra. In de tweede helft van 1999 drongen de artsen van de zoon er bij klaagster op aan dat zij een rechterlijke machtiging zou aanvragen voor de gedwongen opname van haar zoon. De artsen van het psychiatrisch ziekenhuis vonden het niet meer verantwoord dat de zoon de instelling zou verlaten vanwege het gevaar op suïcide. Die machtiging werd om onduidelijke redenen niet aangevraagd. De zoon werd nog wel op vrijwillige basis opgenomen en wist tegen het eind van 1999 diverse malen de instelling, zonder toestemming van de artsen, te verlaten. Hij ging dan vaak naar het huis van klaagster. Tijdens afwezigheid dronk de zoon regelmatig grote hoeveelheden alcohol en werd dan weer teruggebracht naar de instelling.

In april 2000 werd de zoon na een mislukte suïcidepoging op vrijwillige basis weer opgenomen. Binnen een maand verscheen hij niet bij het avondeten in de instelling. De zoon bleek te zijn weggelopen en zich te hebben gesuïcideerd door voor een trein te springen. Klaagster, die op de bewuste dag nog naar de instelling had gebeld en zou worden teruggebeld omdat haar zoon niet kon worden gevonden, stelde de instelling aansprakelijk voor de dood van haar zoon. Gelet op zijn suicidale gedrag en ziekte had volgens haar voorkomen moeten worden dat hij ontsnapte uit de instelling. De hoogste bestuursrechter oordeelde uiteindelijk dat de instelling haar zorgplicht niet had geschonden. Het was niet voorzienbaar dat de zoon, die vaker verdween, zelfmoord zou plegen, zodat er geen causaal verband was tussen het verdwijnen van de zoon en zijn zelfmoord.

Het Hof oordeelt anders. De ziektegeschiedenis van de zoon en in het bijzonder de omstandigheid dat hij drie weken daarvoor getracht had zelfmoord te plegen, hadden volgens het Hof reden moeten zijn voor het instellingspersoneel om te kunnen verwachten dat de zoon wederom een zelfmoordpo- ging zou doen. Het Hof is zich bij dit alles bewust van de trend personen met psychische problematiek te behandelen volgens het principe van minst ingrijpende maatregelen, waaronder het voeren van een 'open deur'-beleid. Dit alles ontslaat overheden niet van hun positieve verplichting tot bescherming van het recht op leven van personen die vanwege een psychiatrische ziekte op vrijwillige basis zijn opgenomen, zeker ingeval er specifieke indicaties zijn die erop duiden dat zij een gevaar vormen voor zichzelf. Ook het Hof had verwacht dat het instellingspersoneel meer beschermingsmaatregelen had genomen dan de beperkte aanwezigheidscontroles die in deze situatie hadden plaatsgevonden. Het Hof concludeert daarom tot een materiële schending van artikel 2 EVRM. Omdat de juridische procedure elf jaar had geduurd constateert het Hof, naast een materiële, ook een procedurele schending van artikel 2 EVRM.

Op verzoek van de Portugese autoriteiten is de zaak inmiddels voorgelegd aan de Grote Kamer van het Hof. Een definitieve uitspraak volgt komend jaar.

Ook in de zaak Mustafayev tegen Azerbeidzjan ${ }^{4}$ klaagde een moeder over het overlijden van haar zoon tijdens detentie. In deze zaak was niet duidelijk of de zoon was komen te overlijden als gevolg van zijn verwondingen na een brand in de cel of, zoals klaagster stelde, ten gevolge van martelingen waaraan de zoon zou hebben blootgestaan. Het door de autoriteiten uitgevoerde onderzoek naar de doodsoorzaak was gebrekkig. De door de autoriteiten overgelegde foto's zijn volgens klaagster van eerdere datum. Nu sprake is van een gestelde schending van het recht op leven moet, volgens het Hof, buiten redelijke twijfel staan wat er is gebeurd. Volgens het Hof zijn de autoriteiten er niet in geslaagd aan te geven waarom er op het moment van de brand geen medisch personeel aanwezig was in de gevangenis en waarom het, na het zien van de zoon van klaagster door een paramedicus, vervolgens uren duurde voor de zoon werd overgebracht naar een ziekenhuis gelegen op $125 \mathrm{~km}$ afstand van de gevangenis.

4 EHRM 4 mei 2017, Mustafayev t. Azerbeidzjan, nr. 47095/09, ECLI:CE:ECHR:2017:0504JUD004709509. 
Het Hof vindt het ook opvallend dat niet direct na de brand werd besloten de zoon over te brengen naar het ziekenhuis, gelet op zijn brandwonden. Het Hof meent dat daarom sprake is van een materiële schending van artikel 2 EVRM, alsook van een procedurele schending wegens het gebrekkige onderzoek naar de doodsoorzaak.

In de Estse zaak Rõigas ${ }^{5}$ was het eveneens een moeder die stelde dat de autoriteiten zich schuldig hadden gemaakt aan een schending van artikel 2 EVRM en van artikel 8 EVRM. In 2006 was bij de zoon van klaagster een kwaadaardig melanoom geconstateerd, waaraan hij werd geopereerd. In 2009 werd een metastase verwijderd uit zijn hersenen. Daarna verminderde zijn gezondheid snel, waarop hij in het ziekenhuis werd opgenomen. Hij onderging daar tal van behandelingen, beweerdelijk zonder dat hij of zijn moeder daarvoor 'informed consent' hadden gegeven. Volgens klaagster is hij daarbij slecht behandeld en zijn verkeerde beslissingen genomen, waardoor de zoon vroegtijdig is komen te overlijden. Na het overlijden is op verzoek van de moeder een onderzoek uitgevoerd en, in tweede instantie, een strafrechtelijk onderzoek. In het kader van dat laatste onderzoek zijn diverse deskundigen en forensische experts gehoord. De openbaar aanklager vond echter te weinig bewijs om te kunnen vermoeden dat in dit geval sprake was geweest van ernstige medische nalatigheid. Gelet daarop is geen strafrechtelijke vervolging tegen de behandelend artsen ingesteld, een besluit dat ook door de Estse rechters in stand is gelaten. Klaagster stelt voor het EHRM allereerst dat onvoldoende onderzoek is verricht naar de omstandigheden in het ziekenhuis en die van het overlijden van haar zoon. Het EHRM overweegt dat het hier gaat om een privaatrechtelijke situatie, waarbij vooral moet worden onderzocht of de autoriteiten hebben voorzien in voldoende mogelijkheden om onderzoek te doen en rechtsherstel te bieden voor het geval er fouten zijn gemaakt. Daarbij merkt het Hof op dat in Estland

5 EHRM 12 september 2017, Rõigas t. Estland, nr. 49045/13, ECLI:CE:ECHR:2017:0912JUD004904513, EHRC 2017/205, m.nt. A.C. Hendriks. zowel een strafrechtelijk kader bestaat dat in de praktijk effectief blijkt te zijn, als een eveneens effectief civielrechtelijk kader. In het onderhavige geval constateert het Hof dat de autoriteiten een zorgvuldig onderzoek hebben ingesteld, waarbij diverse deskundigen zijn gehoord. Met het deskundigenbewijs is bovendien gepast omgegaan, zoals is vereist in een procedure waarin dit type bewijs zo belangrijk is. De deskundigen moeten dan voldoende competent en onafhankelijk zijn, de aan de deskundigen voorgelegde vragen moeten alle relevante aspecten van de zaak betreffen, en de deskundigenrapporten moeten voldoende zijn gemotiveerd. In deze zaak is niet gebleken dat aan die eisen niet zou zijn voldaan. De procedure heeft bovendien niet onredelijk lang geduurd, zodat geen sprake is van een procedurele schending van artikel 2 EVRM. Met betrekking tot artikel 8 EVRM constateert het Hof dat klaagster hier klaagt uit naam van haar zoon en zichzelf. De vraag is of zij inderdaad namens haar zoon kan klagen. Zij kan daarbij niet als indirect slachtoffer worden aangemerkt, nu de kwestie van het geven van toestemming voor medische behandeling een kernaspect vormt van het recht op respect voor het privéleven en als zodanig geen overdraagbaar recht is. De klacht namens de zoon is dan ook niet-ontvankelijk ratione personae. Verder is niet gebleken dat klaagster juridisch gezien bevoegd was om in het ziekenhuis namens haar zoon toestemming te geven, zodat niet kan worden gesteld dat het ziekenhuis haar had moeten vragen om die toestemming. Gelet daarop is ook geen sprake van een schending van artikel 8 EVRM jegens klaagster.

De Grote Kamer van het Hof heeft zich afgelopen kroniekperiode in de Portugese zaak Lopes de Sousa Fernandes ${ }^{6}$ gebogen over de vraag of de echtgenoot van klaagster na een ziekenhuisopname was komen te overlijden als gevolg van een gebrek aan adequate medische zorg. Een Kamer van het Hof had eerder

6 EHRM 19 december 2017, Lopes de Sousa Fernandes t. Portugal (GC), nr. 56080/13, ECLI:CE:ECHR: 2017:1219JUD005608013, EHRC 2018/47, m.nt. L. Lavrysen. 
geoordeeld dat dit wel zo was. ${ }^{7}$ De Grote Kamer, die de feiten anders duidt, oordeelt thans dat hiervan geen sprake is geweest.

Waar ging deze zaak over? Klaagsters echtgenoot was in november 1997 in het ziekenhuis van Vila Nova de Gaia (Portugal) geopereerd aan neuspoliepen. De operatie was succesvol verlopen, maar enkele dagen na ontslag ontstonden er klachten bij de man. De echtgenoot wendde zich toen opnieuw tot het ziekenhuis, maar door een ongelukkige samenloop van gebeurtenissen en een gebrek aan kennis en informatie kwam hij uiteindelijk te overlijden. De Grote Kamer oordeelt dat deze zaak geen betrekking heeft op het onthouden van gezondheidszorg, maar moet worden bezien vanuit het licht van medische nalatigheid. De gestelde gebrekkige samenwerking tussen ziekenhuisafdelingen wijst niet op een disfunctionerend ziekenhuissysteem. Wel is sprake geweest van een onevenredig lange duur van de betrokken gerechtelijke procedures en was het doodsoorzaakonderzoek onvoldoende grondig. De Grote Kamer laat de procedurele schending van artikel 2 EVRM daarom wel in stand. Met betrekking tot de materiële schending van artikel 2 EVRM overweegt de Grote Kamer dat in zaken waarin beweerdelijk sprake is geweest van medische nalatigheid, de positieve verplichtingen voor overheid die besloten liggen in artikel 2 EVRM zich in principe beperken tot het opleggen van een verplichting om te reguleren. Staten moeten met andere woorden voorzien in een juridisch kader dat ziekenhuizen - zowel publieke als private - verplicht om geschikte maatregelen te nemen om de levens van patiënten te beschermen. Bovendien moeten zij het effectieve functioneren van een dergelijk kader garanderen, in het bijzonder door het nemen van de noodzakelijke maatregelen ter implementatie, toezicht en handhaving. Slechts in 'uitzonderlijke omstandigheden' kunnen de autoriteiten verantwoordelijk worden gehouden voor de handelingen of nalatigheden van zorgverleners. Dergelijke omstandigheden bestaan wanneer het leven van een patiënt bewust in gevaar wordt gebracht door het weigeren van levensreddende spoedbehandeling. Uitzonderlijke omstandigheden bestaan daarnaast ook wanneer systemisch of structureel disfunctioneren in de ziekenhuisdienst ertoe leidt dat een patiënt toegang wordt ontzegd tot een levensreddende spoedbehandeling, terwijl de autoriteiten weten of zouden moeten weten van het bestaan van dergelijk risico, maar nalaten de noodzakelijke maatregelen te nemen om het doen ontstaan van dat risico te voorkomen.

Volledigheidshalve wijs ik op de uitvoerige bespreking van rechter Pinto de Albuquerque over het recht op gezondheidszorg in zijn gedeeltelijke dissenting opinion bij deze uitspraak.

\section{- Optreden politie bij psychiatrische patiënten}

In de uit Slovenië afkomstige zaak Štefančič $\check{c}^{8}$ moest het Hof oordelen over de vraag of het overlijden van de zoon van klaagster rond zijn aanhouding gekwalificeerd moet worden als een schending van artikel 2 EVRM. Branko Štefančič leed aan paranoïde schizofrenie en depressies. Hij was daarvoor diverse malen opgenomen in een psychiatrisch ziekenhuis. Nadat hij was langsgeweest bij het openbaar ministerie en daar te kennen had gegeven dat hij de volgende dag zou terugkeren en iedereen zou doodschieten, werd besloten hem in te rekenen en over te brengen naar een psychiatrisch ziekenhuis. Bij zijn aanhouding werd vanwege verzet van Branko, de zoon van klaagster, door het interventieteam geweld gebruikt. Het interventieteam probeerde hem te kalmeren, maar dit lukte maar deels. De zoon van klaagster moest vervolgens overgeven, rakte buiten bewustzijn en kwam te overlijden. De leden van het interventieteam hebben Branko vervolgens tevergeefs getracht te reanimeren. Volgens de autoriteiten is de zoon van klaagster komen te overlijden door verstikking. Dit wordt door klaagster, die getuige is geweest van de aanhouding, weersproken. Zij meent dat het overlijden het gevolg is van het politiegeweld. Het Hof constateert dat de

7 EHRM 15 december 2015, Lopes de Sousa Fernandes t. Portugal, nr. 56080/13, GJ 2016/33, m.nt. A.C. Hendriks.

8
EHRM 24 oktober 2017, Štefančič t. Slovenië, nr.
58349/09, ECLI:CE·ECHR·2017:1024JUD005834909. 
zoon was komen te overlijden in het kader van zijn aanhouding door de politie in de aanwezigheid van een medisch team. De autoriteiten hadden aldus de controle over de situatie en dienen in dergelijke gevallen adequate medische zorg te kunnen bieden. Dat geldt ook in het geval dat wordt besloten om geweld in te zetten. Over de wijze waarop de autoriteiten zorg hebben ingezet bestaat geen duidelijkheid. Het forensisch onderzoeksrapport dat door de autoriteiten is overgelegd laat veel vragen onbeantwoord, waardoor niet komt vast te staan hoe Branko nu precies is komen te overlijden en of de autoriteiten goede zorg hadden geboden aan hem. In deze context levert het overlijden van de zoon een schending op van artikel 2 EVRM.

De Franse zaak Boukrourou e.a. ${ }^{9}$ vertoont overeenkomsten met de zojuist besproken zaak Štefančič. M.B., een man met psychiatrische klachten, was komen te overlijden tijdens een politieactie na een ruzie in een apotheek over geneesmiddelen. Het Hof constateert in deze zaak dat er geen causaal verband bestond tussen het politieoptreden en het overlijden van M.B. De politie had namelijk geen intrinsiek dodelijk geweld gebruikt. Zelfs als er een causale relatie was geweest tussen het geweld van de politie en de dood van M.B., dan zou de dood niet voorzienbaar zijn geweest. De politieagenten wisten namelijk niet van de hartproblemen van M.B. en het gevaar van de maatregelen was niet voorzienbaar als gevolg van de combinatie van stress en hartproblemen. De omstandigheid dat de politie snel om hulp had verzocht en de hulpdiensten spoedig waren verschenen, toont aan dat de politie niet nalatig was geweest met betrekking tot het naleven van de in artikel 2 EVRM besloten liggende verplichtingen. Niettemin constateert het EVRM een schending van artikel 3 EVRM. De behandeling die de politie had toegepast, te weten herhaald geweld, vormt in de optiek van het Hof een schending van artikel 3 EVRM.

9

EHRM 16 november 2017, Boukrourou e.a. t. Frankrijk, nr. $\quad 30059 / 15, \quad$ ECLI:CE:ECHR: 2017:1116JUD003005915, EHRC 2018/39, m.nt. J.M. ten Voorde.

\section{- Beëindigen levensverlengend handelen}

De klacht in de Franse zaak Afiri en Biddarri ${ }^{10}$ betreft het besluit van een Frans behandelteam om de levensverlengende behandeling aan de 14-jarige dochter van klagers te beëindigen. Dochter verkeerde in een permanent vegetatieve staat na een acute hartstilstand. De ouders wilden kunnen beslissen over de verdere behandeling. Zij waren door het behandelteam wel gehoord, maar het team had een ander besluit genomen.

Het Hof verklaart de klacht van de ouders niet-ontvankelijk. Het oordeelt dat het Franse juridische kader met betrekking tot het besluit om een behandeling te beëindigen voldoet aan de eisen met betrekking tot artikel 2 EVRM. Ook de wijze waarover besluiten worden genomen inzake het beëindigen van een behandeling is voldoende duidelijk, ondanks het feit dat ouders het niet eens zijn met de uitkomst van het besluitvormingsproces. Het Hof oordeelt voorts dat het Franse recht ook voorziet in juridische toetsing van het besluitvormingsproces.

Het Hof besluit in de zaak Haastrup ${ }^{11}$ eveneens de klacht van de ouders inzake het beëindigen van de behandeling van hun zoon Isaiah niet-ontvankelijk te verklaren. ${ }^{12}$ Isaiah lag sinds zijn geboorte in een Brits ziekenhuis voor levensreddende zorg. Als Isaiah twaalf maanden oud is, willen de artsen de verdere levensreddende zorg staken. De ouders verzetten zich daartegen. Nadat het Hof beschikt over informatie inzake het feitenrelaas, verklaart het Hof de klachten van de ouders niet-ontvankelijk. Op basis van al het voorliggende materiaal concludeert het Hof dat er geen sprake lijkt te zijn van een schending van de rechten en vrijheden van het EVRM.

10 EHRM 23 januari 2018, Afiri en Biddarri t. Frankrijk (ontv.besl.), nr. 1828/18, ECLI:CE:ECHR: 2018:0123DEC000182818, EHRC 2018/51, m.nt. A.C. Hendriks.

11 EHRM 6 maart 2018, Haastrup t. het VK (ontv.besl.), nr. $9865 / 18$.

12 EHRM 6 maart 2018, Haastrup t. het VK (ontv.besl.), nr. $9865 / 18$. 


\section{- Recht op een experimentele behandeling}

Tegenover de vraag of een behandeling mag worden beëindigd, staat de vraag of de overheid moet toestaan dat een patiënt een potentieel levensverlengende experimentele behandeling mag ondergaan. Deze vraag was aan de orde in de Britse zaak Gard. ${ }^{13}$ Ook deze zaak draaide om het staken van de behandeling aan een ernstig ziek kind. Charlie Gard, geboren op 4 augustus 2016, was een baby die leed aan een zeldzame en dodelijke erfelijke ziekte. In februari 2017 had het behandelend ziekenhuis de rechtbank (High Court) verzocht de behandeling van Charlie te staken en enkel nog palliatieve zorg te verlenen. De ouders hadden tegelijkertijd bij de rechtbank het verzoek ingediend te oordelen dat het in het belang van Charlie was om in de Verenigde Staten een experimentele behandeling te ondergaan. De rechtbank oordeelde dat het rechtmatig was de behandeling te staken, omdat het aannemelijk was dat Charlie significante schade zou lijden als zijn huidige lijden werd verlengd zonder dat er enig reëel vooruitzicht op verbetering was, en de experimentele behandeling geen positief effect zou hebben. Dit oordeel werd door het hof van beroep (Court of Appeal) en het hoogste gerechtshof (Supreme Court) in stand gehouden.

De ouders dienden daarop, namens Charlie en zichzelf, een klacht in bij het EHRM. Zij stelden zich op het standpunt dat artikel 2 EVRM en artikel 5 EVRM zouden worden geschonden als Charlie geen toegang kreeg tot een experimentele behandeling en het ziekenhuis Charlie zou beletten het ziekenhuis te verlaten. De ouders kwalificeerden het laatste als vrijheidsberoving. Ook meenden zij dat de uitspraken van de nationale rechters een schending van artikel 6 en artikel 8 EVRM opleverden.

Het Hof overweegt dat er een ruime beoordelingsvrijheid toekomt aan de autoriteiten indien het om de toegang tot een experimentele behandeling gaat bij een terminaal zieke persoon, alsmede in geval van gevoelige morele en ethische zaken. Vanuit dat

13 EHRM 28 juni 2017, Gard e.a. t. het VK (ontv.besl.), nr. 39793/17, ECLI:CE:ECHR:2017:0627DEC003979317, EHRC 2017/193, m.nt. J.H. Gerards, GJ 2017/125, m.nt. A.C. Hendriks. perspectief kent het Hof belang toe aan de omstandigheid dat er een nationaal juridisch kader was vergelijkbaar met het EVRM - dat zowel betrekking had op toegang tot experimentele behandeling als het staken van een geneeskundige behandeling. Daar komt bij dat de nationale gerechten grondig naar de zaak hadden gekeken, dat de uitspraken uitvoerig waren gemotiveerd, met voldoende argumenten ter onderbouwing van de conclusies. De nationale gerechten hadden ook contact gehad met alle rechtstreeks betrokkenen, inclusief een onafhankelijke deskundige die was aangewezen door de Britse Jeugdzorg. De gerechten hadden ook een deskundigenrapport van artsen met internationaal aanzien ontvangen en hadden het ziekenhuis bezocht. Op basis van al het vergaarde bewijsmateriaal hadden de gerechten geconcludeerd dat het zeer waarschijnlijk was dat Charlie continu werd blootgesteld aan pijn, lijden en stress, en dat het geenszins aannemelijk was dat het ondergaan van een experimentele behandeling tot enige verbetering in zijn situatie zou leiden, maar slechts langer lijden tot gevolg zou hebben. Het Hof verklaart de klachten van Charlie en zijn ouders daarop in meerderheid niet-ontvankelijk.

\section{- Procedurele overheidsplichten}

Zoals eerder aangehaald omvat artikel 2 EVRM de procedurele plicht om overlijdensgevallen zorgvuldig en spoedig te onderzoeken en de plicht zo nodig nadere, al dan niet strafrechtelijke, maatregelen te nemen jegens de voor het overlijden van personen verantwoordelijken.

De zaak Ioniță $\breve{a d}^{14}$ had betrekking op de dood van de zoon van klagers, in 2005, in Roemenië na het ondergaan van een operatie. De zoon had meerdere erfelijke aandoeningen en was op vierjarige leeftijd in het ziekenhuis geopereerd ter verwijdering van poliepen. Dit was gebeurd onder algehele anesthesie. Na de ingreep werd de jongen direct overgebracht naar de afdeling intensive care, alwaar werd geconstateerd dat hij blauw aanliep en geen pols-

14 EHRM 10 januari 2017, Ioniță t. Roemenië, nr. 81270/12, ECLI:CE:ECHR:2017:0110JUD008127012. 
druk had. Bij de jongen was een hersenbloeding ontstaan en het bloed was in zijn longen gekomen. Twee uur na de operatie werd de jongen, ondanks pogingen hem te reanimeren, dood verklaard. Nog dezelfde dag werd een strafrechtelijk onderzoek gestart, in het kader waarvan de artsen verklaringen aflegden. Uit een autopsierapport van een forensisch team kwam naar voren dat er na de operatie complicaties waren opgetreden bij de jongen, in het bijzonder ademhalingsproblemen als gevolg van de hersenbloeding, een conclusie die door een hogere onderzoekscommissie werd onderschreven. De vader startte daarop een tuchtrechtelijke procedure. De lagere tuchtrechter constateerde dat de artsen deels nalatig waren geweest. In hoger beroep werden de artsen veroordeeld tot het betalen van $€ 220$ schadevergoeding wegens het niet nemen van de noodzakelijke preoperatieve voorzorgsmaatregelen. Tevens was er volgens het Roemeense centraal tuchtcollege geen sprake van 'informed consent' van de zijde van de ouders. De ouders startten in 2005 ook een strafrechtelijke procedure, in het kader waarvan de politie nader onderzoek deed naar het handelen van één arts en er diverse forensische onderzoeksrapporten werden opgesteld, omdat eerdere verklaringen en rapporten tegenstrijdigheden bevatten. In 2008 concludeerde de openbaar aanklager dat er geen aanwijzingen waren voor strafrechtelijke nalatigheid en beëindigde het strafrechtelijke onderzoek. De ouders tekenden bezwaar aan tegen dit besluit, maar deze bezwaren werden door de strafrechter in twee instanties afgewezen. De ouders startten ook een civiele aansprakelijkheidsprocedure, die afhankelijk was van de uitkomsten van het strafrechtelijke onderzoek. In 2013 staakten de ouders deze procedure.

Het Hof stelt allereerst vast dat er voor verdragsstaten op grond van artikel 2 EVRM geen verplichting bestaat om strafrechtelijk op te treden na het overlijden van een persoon waarbij geen sprake is geweest van opzet. Indien er mogelijk sprake was van medische nalatigheid kan aan de in artikel 2 EVRM besloten liggende verplichting ook worden voldaan door een effectieve civielrechtelijke rechtsgang te creëren ter vaststelling van aansprakelijkheid en een eventu- ele compensatieplicht, zoals het toekennen van schadevergoeding en het publiceren van de uitspraak. Tuchtrechtelijke procedures kunnen ook zijn voorzien. Aan de in artikel 2 EVRM besloten liggende verplichtingen is evenwel niet voldaan indien deze rechtsbescherming uitsluitend in theorie bestaat. Het Hof heeft eerder geconstateerd dat de rechtsbescherming in Roemenië bij dit soort zaken gebrekkig is. In de onderhavige procedures voor de nationale rechter wijst het Hof erop dat belangrijke vragen onbeantwoord zijn gebleven en dat er voor tegenstrijdigheden tussen rapporten en getuigenissen geen eensluidende verklaring is gekomen. Het Hof vindt het voorts van belang dat er volgens de tuchtcolleges geen sprake was van 'informed consent', terwijl de overledene bekend was met erfelijke aandoeningen. Het Hof tilt ook zwaar aan het feit dat de procedure alles bij elkaar jaren heeft geduurd en dat dit niet aan de ouders heeft gelegen. Voor het Hof vormt dit reden om te concluderen dat de in artikel 2 EVRM besloten liggende procedurele verplichting was geschonden.

Ook in een Russische overlijdenszaak constateerde het Hof dat de autoriteiten de procedurele verplichtingen van artikel 2 EVRM hadden geschonden. De zaak Agarkova ${ }^{15}$ ging over de zoon van klaagster, die in 2007 naar het ziekenhuis was overgebracht. De zoon was betrokken geweest bij een vechtpartij, waaraan hij ernstige verwondingen had overgehouden. In het ziekhuis was de zoon in coma beland en enkele weken later overleden. Een maand na het overlijden was een strafrechtelijk onderzoek opgestart. De autoriteiten stelden vast dat het hersenletsel was ontstaan na de vechtpartij met een zekere V. Tegen V. begint daarop een strafrechtelijk onderzoek wegens een vermoeden van doodslag. Deze zaak is evenwel nooit aan de rechter voorgelegd, doordat er steeds vertraging optrad bij het onderzoek. Klaagster heeft meermaals de autoriteiten hierop aangesproken. De autoriteiten moeten de zaak nog steeds nader onderzoeken en voor de vertraging is geen verklaring gegeven. Het Hof consta-

15 EHRM 15 mei 2018, Agarkova t. Rusland, nr. 29951/09, ECLI:CE:ECHR:2018:0515JUD002995109. 
teert daarop een procedurele schending van artikel 2 EVRM en kent klaagster een immateriële schadevergoeding toe van $€ 20.000$ plus een vergoeding van de door haar gemaakte kosten en uitgaven.

Een derde procedurele schending van artikel 2 EVRM deed zich voor in de zaak Vlase. ${ }^{16}$ Klagers in deze zaak zijn de vrouw en de dochter van de heer Vlase, die op 13 januari 2012 in het militair ziekenhuis van Braşov (Roemenië) was komen te overlijden. Hij had daar eerder, op 7 december 2011, een geneeskundig onderzoek ondergaan. Bij de heer Vlase werd een maagzweer geconstateerd als gevolg van een bacteriële infectie. Na een operatie onderging hij, vanwege de complicaties, twee nieuwe operaties, uitgevoerd door hetzelfde medische team. Aansluitend werd bij hem een voedingsbuis geïnstalleerd. Op 6 januari 2012 werden nieuwe bacteriën bij hem ontdekt. Ten gevolge van een hersenbloeding, op 9 januari 2012, ging zijn gezondheid vervolgens snel achteruit en overleed de heer Vlase op 13 januari 2012.

De klagers dienden een klacht in wegens doodslag. Daarop wordt direct een strafrechtelijk onderzoek gestart waarbij diverse deskundigen worden gehoord. In augustus 2014 beklaagden klagers zich over het gebrek aan voortgang met betrekking tot het onderzoek. Op 22 september 2014 start de officier van justitie een officieel strafrechtelijk onderzoek naar doodslag. Op 3 juni 2015 besluit het openbaar ministerie de zaak te sluiten omdat de aanklagers geen begin van bewijs voor medische nalatigheid hadden gevonden. Klagers betwisten dit besluit, maar werden in het ongelijk gesteld. Daarop start een proces van beroep, hoger beroep en terugverwijzen van de zaak, een proces dat tot op de datum van de uitspraak van het Hof nog niet was afgerond. Vanwege de duur van dit proces, waarbij het nationaal juridisch systeem er niet in was geslaagd een adequaat en voldoende snel antwoord te vinden voor de uitstaande vragen, constateert het Hof een procedurele schending van artikel 2 EVRM. ECLI:CE:ECHR:2018:0724JUD008078413.

\subsection{Verbod van foltering en gebod van menselijke behandeling (art. 3 EVRM)}

Artikel 3 EVRM legt aan de nationale autoriteiten, naast onthoudingsverplichtingen, diverse positieve verplichtingen op ter voorkoming van foltering en ter waarborging van de menselijke behandeling van personen. Artikel 3 EVRM kent aldus grote overeenkomsten met artikel 2 EVRM. Ook bij artikel 3 EVRM maakt het Hof onderscheid tussen materiële en procedurele verplichtingen.

\section{- $\quad$ Adequate medische zorg}

Klachten over het ontbreken van toegang tot adequate medische zorg kunnen naast artikel 2 EVRM zijn gebaseerd op artikel 3 EVRM. Bij een beroep op artikel 3 EVRM gaat het doorgaans om het lijden dat het ontbreken van adequate zorg voor de betrokkene heeft veroorzaakt. Het Hof ontvangt in het bijzonder klachten van gedetineerden die stellen dat de zorg in penitentiaire inrichtingen en andere instellingen waar mensen onvrijwillig zijn opgenomen ernstig te wensen overlaat. ${ }^{17}$

De Belgische zaak Gengoux ${ }^{18}$ is een voorbeeld van zo'n zaak. In deze casus gaat het over de vraag of sprake was geweest van gebrekkige medische zorg in een penitentiaire instelling. De vader van klager was in oktober 2010 opgenomen in het ziekenhuis wegens ademhalingsproblemen. Er werd bij hem kanker geconstateerd en de vader stemde in met chemotherapie. Twee maanden later werd de vader aangehouden onder verdenking van vuurwapengeweld onder invloed van alcohol. Hij werd in voorlopige hechtenis genomen. Het hoofd van de medische dienst werd geïnformeerd over de gezondheidsproblemen. De chemotherapie werd in detentie gecontinueerd. Een door klager zelf gekozen arts verklaarde vervolgens dat, niettegenstaande de zorg die de vader in detentie ontving, de detentieomstan-

17 Zie ook EHRM 7 september 2017, Mirzashvili t. Georgië, nr. 26657/07, ECLI:CE:ECHR: 2017:0907JUD002665707.

18 EHRM 17 januari 2017, Gengoux t. België, nr. 76512/11, ECLI:CE:ECHR:2017:0117JUD007651211, EHRC $2017 / 72$. 
digheden in de weg stonden aan de adequate behandeling van vader en dat de gezondheid en levensverwachting van vader achteruitgingen. Drie maanden later verklaarde deze arts nogmaals dat de gezondheid van vader dramatisch achteruit was gegaan. Verzoeken om beëindiging van de voorlopige hechtenis werden door de autoriteiten afgewezen. In mei 2011 overleed de vader van klager aan de gevolgen van de eerder bij hem vastgestelde kanker.

Het Hof wijst de gestelde schendingen van artikel 2 en 3 EVRM van de hand. Met betrekking tot artikel 2 EVRM overweegt het Hof dat de autoriteiten de detentie van vader vanwege zijn gezondheidsklachten hadden kunnen beëindigen. Het Hof heeft evenwel geen reden om de autoriteiten te bekritiseren. Tijdens detentie is vader geen adequate zorg onthouden en het overlijden is het gevolg geweest van de bij hem bestaande gezondheidsklachten. Het Hof heeft geen oorzakelijk verband kunnen leggen tussen het overlijden en het detentieregime, zoals een infectie of een gebrekkig immuunsysteem.

Met betrekking tot artikel 3 EVRM overweegt het Hof dat vader goede zorg had gekregen en dat de gevangenisautoriteiten alles in het werk hadden gesteld om de huisarts van vader te bereiken toen zijn gezondheid sterk achteruitging en hem naar een beter geëquipeerde ziekenhuisafdeling hadden overgebracht. De nationale rechter had ook een zorgvuldige afweging gemaakt met betrekking tot de vraag of een verlengde hechtenis van vader verantwoord was, gelet op zijn gezondheid. Vanaf het moment dat een ziekenhuisopname noodzakelijk was, hebben de autoriteiten daaraan ook gehoor gegeven. Er heeft daarom geen schending van artikel 3 EVRM plaatsgevonden.

In de zaak Bulak ${ }^{19}$ boog het Hof zich over de detentieomstandigheden van een gehandicapte man in Polen. Klager was bij een auto-ongeluk ernstig gewond geraakt, en was daarvoor behandeld in Duitsland. Omdat hij in Polen van diverse misdrijven werd verdacht, werd hij uitgewezen naar Polen en daar in voorlopige hechtenis genomen. Klager beklaagde zich over de detentieomstandigheden tijdens de herhaaldelijk verlengde voorlopige hechtenis. Zo kreeg hij een cel toegewezen op de eerste verdieping van de instelling en was hij afhankelijk van medegedetineerden om hem naar de bewegingsruimte te brengen. Hoewel het Hof herhaalt dat er geen recht bestaat op vrijlating uit detentie bij een handicap, benadrukt het Hof dat de zorg wel adequaat moet zijn. Aan dit laatste was in deze zaak niet voldaan. Door artsen voorgeschreven aanpassingen waren aangebracht, maar de implementatieperiode had onverklaarbaar lang geduurd. Als gevolg van dit alles was de gezondheid van klager tijdens detentie achteruitgegaan en was hij in een afhankelijke positie ten opzichte van medegedetineerden geplaatst. Zijn detentieomstandigheden ondermijnden zijn waardigheid en dit leidde tot een vorm van acuut lijden. Materiële schending van artikel 3 EVRM.

Ook de zaak Kitiashvili ${ }^{20}$ betrof een zaak over de medische zorg tijdens detentie, ditmaal in Georgië. Volgens het Hof hadden de klachten van klager betrekking op de gestelde vertraging die optrad bij de behandeling van klagers tbc, het gestelde gebrek met betrekking tot de behandeling van de neurologische klachten van klager en een aantal overige klachten. In dit geval wijst het Hof de klachten af. Het Hof stelt vast dat klager, die eerder in zijn leven tbc had gehad, binnen een maand na constatering van de tbc daaraan was geholpen. Hij werd overgeplaatst naar een aparte voorziening voor gedetineerden met tbc, maar teruggestuurd nadat hij de interne regels had overtreden. Voor zijn andere gezondheidsklachten is hij volgens het Hof eveneens adequaat behandeld. Zo had hij regelmatig toegang tot een neuroloog. Het Hof erkent dat de klachten complex waren door de multimorbiditeit. Hierdoor heeft het vinden van een gepaste behandeling soms even geduurd. Dat maakt niet dat sprake is geweest van schending van artikel 3 EVRM.

20 EHRM 23 november 2017, Kitiashvili t. Georgië, nr. 37747/08, ECLI:CE:ECHR:2017:1123JUD003774708. 
De Roemeense zaak Dorneanu ${ }^{21}$ betreft de leefomstandigheden van en de zorg aan een gedetineerde met terminale prostaatkanker, die acht maanden na detentie was komen te overlijden. De betrokkene moest een gevangenisstraf uitzitten na veroordeling wegens een economisch delict. Hij was vlak daarvoor gediagnosticeerd met prostaatkanker en de ernst van de ziekte stond vast op het moment dat zijn vrijheidsstraf zou beginnen. Aanvankelijk kreeg hij daarom drie maanden uitstel om gezondheidsredenen, maar na beroep van de openbaar aanklager werd dit besluit weer ingetrokken. De man heeft daarna in de gevangenis gezeten, afgewisseld met vele bezoeken aan het ziekenhuis. Nog in hetzelfde jaar is hij overleden, maar zijn nabestaanden willen de zaak voortzetten. De klacht over de gestelde schending van artikel 3 EVRM vanwege de gestelde onverenigbaarheid van de zorg met deze bepaling verklaart het Hof kennelijk ongegrond omdat die zorg wel toereikend is geweest. De vraag is echter of de omstandigheden van zijn detentie wel verenigbaar waren met hetzelfde artikel 3 EVRM. Het Hof constateert dat hij heel weinig persoonlijke ruimte had (op een bepaald moment minder dan $3 \mathrm{~m}^{2}$ ), terwijl de cellen ook niet waren ingericht voor iemand met een ernstige ziekte als hij. De vraag is of in die omstandigheden de betrokkene niet had moeten worden vrijgelaten. Het Hof weegt daarbij mee dat de vele bezoeken aan het ziekenhuis en de ernst van de ziekte een zeer zware belasting moeten hebben gevormd voor de betrokkene, waarbij het steeds moeilijker werd om de gevangenisomstandigheden te verdragen. Op basis van humanitaire overwegingen hadden de autoriteiten dan maatregelen kunnen treffen. Dat was hier temeer redelijk geweest nu de betrokkene zich goed gedroeg in de gevangenis en er weinig risico op recidive bestond. Daardoor is de realiteit van de situatie van betrokkene niet voldoende beoordeeld door de nationale autoriteiten, waardoor betrokkene de mogelijkheid is ontnomen zijn laatste dagen in

21 EHRM 28 november 2017, Dorneanu t. Roemenië, nr. 55089/13, ECLI:CE:ECHR:2017:1128JUD005508913, EHRC 2018/40. waardigheid door te brengen. Schending van artikel 3 EVRM.

\section{- Detentieomstandigheden}

De verplichting voor de overheid om te voorkomen dat de waardigheid van personen wordt aangetast, kan ook het gevolg zijn van detentieomstandigheden die te wensen overlaten. Van een schending van deze (positieve) verplichting was sprake in de Turkse zaak Ebedin Abin.22

Klager in deze zaak beklaagde zich erover dat hij in de periode 2008-2009, toen hij in de Erzurumgevangenis verbleef, geen maaltijden kreeg die geschikt voor hem waren, gelet op de diëten die de artsen hem hadden voorgeschreven vanwege zijn gezondheidsstatus. Zijn gezondheidsstatus is daarop achteruitgegaan. Het Hof stelt vast dat de autoriteiten niet de noodzakelijke maatregelen hadden getroffen om de gezondheid en het welzijn van klager te beschermen, ter voorkoming van de achteruitgang van de gezondheidsstatus van klager. Dat de autoriteiten klager de optie hadden geboden om zelf - en op eigen kosten - voeding te bestellen of betaalde maaltijden in de kantine te eten wijst het Hof als rechtvaardigingsgrond van de hand. Het Hof constateert een schending van artikel 3 EVRM.

\section{- Bescherming integriteit jeugdigen}

Net als jegens gedetineerden hebben de autoriteiten een bijzondere beschermingsplicht jegens jeugdigen. Het tekortschieten bij het bieden van jeugdzorg kan in situaties van seksueel misbruik en gedwongen prostitutie van een jeugdige een schending van artikel 3 EVRM opleveren. Aldus het Hof in de Italiaanse zaak V.C. ${ }^{23}$

Het feitenrelaas in deze zaak was kort samengevat als volgt. Na het overlijden van haar grootmoeder, in 2010, ontwikkelde V.C. tekenen van een depressie. Zij werd gediagnosticeerd als hebbende een

22 EHRM 13 maart 2018, Ebedin Abi t. Turkije, nr. 10839/09, ECLI:CE:ECHR:2018:0313JUD001083909, EHRC 2018/92.

23 EHRM 1 februari 2018, V.C. t. Italië, nr. 54227/14, ECLI:CE:ECHR:2018:0201JUD005422714, EHRC 2018/82, m.nt. R.S.B. Kool. 
bipolaire stoornis met borderline. Daarop volgde een lange periode van tekortkomingen van de zorg aangeboden door jeugdzorg, waarbij sprake was van een parallelle interventie door de verslavingszorg. Door de officier van justitie, de procureur bij de (civiele) jeugdrechtbank en de jeugdrechter werd afwisselend getracht om maatregelen te treffen die V.C. zouden kunnen beschermen tegen risico's vanuit de kringen waarin zij verkeerde, onder andere tegen seksuele exploitatie. Een spoedverzoek tot het treffen van maatregelen werd door de jeugdrechter gehonoreerd in de vorm van een ondertoezichtstelling en een opdracht tot plaatsing van V.C. in een instelling. Die werd niet uitgevoerd vanwege een tekort aan plaatsen en de weigering van V.C. om zich te laten opnemen. Intussen raakte V.C. verzeild in een prostitutienetwerk. Later in 2013 werd zij slachtoffer van een groepsverkrachting. In 2014 oordeelde de jeugdrechter opnieuw dat V.C. onmiddellijk moest worden opgenomen. Jeugdzorg was echter van mening dat plaatsing in een afkickkliniek was geïndiceerd, wat leidde tot uitstel van plaatsing. Ook de besluitvorming binnen de jeugdrechtbank verliep traag, waarbij vanuit de jeugdzorg niet werd gereageerd op de voorlichtingsverzoeken. De uiteindelijke plaatsing leidde in eerste instantie tot verdere gedragsproblemen bij V.C., maar in 2016 concludeerden de betrokken instellingen, in het bijzonder de verslavingszorg, dat behandeling niet meer nodig was. V.C. keerde terug naar het ouderlijk huis en de procedure werd beëindigd. Vanuit de jeugdzorg, niet zijnde de verslavingszorg, werd geen begeleiding geboden bij het re-integratietraject.

Tussentijds werd vanuit de strafrechtspleging meer voortvarend gereageerd op het door de ouders gecommuniceerde risico op seksuele exploitatie. Direct na de melding werd in 2013 een strafrechtelijk onderzoek gestart, uitmondend in een veroordeling van twee mannen die V.C. hadden ingezet als prostituee. Ook de groepsverkrachting waarvan V.C. eind 2013 slachtoffer werd leidde tot een strafzaak; ten tijde van de behandeling van de zaak door het Hof was deze nog niet afgerond.

Klaagster heeft over het uitblijven van een adequaat hulpaanbod in juli 2014 een klacht ingediend bij het
EHRM wegens schending van artikel 3, 8 en 13 EVRM. Het Hof beoordeelt de zaak op een mogelijke schending van artikel 3 en 8 EVRM, nadat een door de Italiaanse regering gevoerd ontvankelijkheidsverweer is verworpen. Het Hof constateert aan de hand van de bekende criteria dat artikel 3 EVRM van toepassing is, en beziet dit, zoals het eerder heeft gedaan, in samenhang met artikel 8 EVRM. Het benadrukt dat de nationale autoriteiten uit hoofde van artikel 3 en 8 EVRM voortvloeiende positieve verplichtingen gehouden zijn tot het bieden van daadwerkelijke en effectieve bescherming. Met inachtneming van het kennisvereiste en de beoordelingsmarge gegund met het oog op de complexe taak van de overheid om sturing te geven aan de moderne samenleving, benadrukt het Hof het belang van prompt en voortvarend optreden, in het bijzonder in situaties waarin sprake is van reële en onmiddellijke dreiging voor de fysieke en geestelijke integriteit van minderjarigen. In het bijzonder is daarbij een rol weggelegd voor de politie en de strafrechtelijke autoriteiten. Maar ook vanuit de civiele jeugdbescherming dient adequaat te worden gehandeld. Gepast optreden door de strafrechtelijke autoriteiten vormt echter geen compensatie voor ernstige tekortkomingen vanuit het parallelle civiele traject. Het Hof constateert een schending van artikel 3 en 8 EVRM.

\subsection{Recht op vrijheid en veiligheid (art. 5 EVRM)}

Artikel 5 EVRM beschermt het recht op vrijheid en veiligheid. Aldus biedt deze bepaling onder meer bescherming tegen willekeurige vrijheidsontneming, bijvoorbeeld vanwege een (vermeende) lichamelijke of geestelijke ziekte bij de betrokkene (art. 5 , lid 1). Deze bepaling biedt individuen ook een aantal procedurele rechten ter bescherming van hun vrijheid en veiligheid. Tot die rechten behoren het recht om de rechter te verzoeken de rechtmatigheid van de vrijheidsbeneming te toetsen (art. 5, lid 4) en het recht op financiële compensatie bij onrechtmatige vrijheidsontneming (art. 5, lid 5). 


\section{- Vrijheidsontneming bij psychiatrische patiënten} In zaken waarin personen wegens een gestelde geestesziekte in een instelling worden opgenomen, wordt regelmatig een beroep gedaan op artikel 5 lid 1 EVRM. Zo ook in de Roemeense zaak N. ${ }^{24}$

N., een in 1959 geboren man, had zich in Straatsburg erover beklaagd dat zijn detentie in een psychiatrische instelling was verlengd zonder dat er een spoedige rechterlijke beoordeling had plaatsgevonden over de noodzaak daarvan en zonder dat uitspraken van de rechtbank, waarin was bevolen dat $\mathrm{N}$. in vrijheid diende te worden gesteld, werden nageleefd. Het Hof stelt vast dat er in ieder geval sinds 11 september 2007 geen juridische basis meer was voor de detentie van klager, omdat de nationale rechter toen had vastgesteld dat er geen sprake was van gevaar dat een gedwongen opname rechtvaardigde. Het Hof oordeelt eveneens dat de vrijheidsbeneming sinds 29 augustus 2016 willekeurig is, omdat de nationale rechter toen het belang van invrijheidstelling onderstreepte. Tussentijds, in 2007, had de nationale rechter bevolen dat N. moest worden vrijgelaten onder de voorwaarde dat werd voorzien in zijn behoeften. Deze uitspraak was niet nagekomen, hetgeen volgens het Hof de tegenwoordige omstandigheden van het Roemeense rechtssysteem weerspiegelt. Daarnaast oordeelt het Hof dat de juridische procedures met betrekking tot de noodzaak van de verlenging van N.'s vrijheidsbeneming sinds 2007 onvoldoende juridische waarborgen boden aan N. N. had evenmin voldoende juridische bijstand gekregen bij deze procedures en werd telkens bijgestaan door verschillende advocaten. N. had evenmin de gelegenheid gekregen om voor de procedures met hen te overleggen. Volgt een schending van artikel 5 lid 1 en 4 EVRM.

Ook in Rusland worden de waarborgen ter voorkoming van willekeurige vrijheidsontneming niet altijd nauwlettend nageleefd. Zo ook in de zaak $X,{ }^{25}$ van een man die zich graag als vrouw wilde kleden en die ervan werd verdacht een psychische stoornis te hebben. In deze zaak toetst het Hof de detentie van klager nauwlettend aan de bekende criteria van het Winterwerp-arrest. ${ }^{26}$ Het Hof accepteert in deze zaak dat de artsen en autoriteiten zijn uitgegaan van een psychische stoornis. Tegelijkertijd is niet gebleken dat klager ook een gevaar voor zichzelf of anderen vormt. Niet duidelijk is waaruit het lastigvallen van een jongen door klager bestond en of deze jongen een klacht had ingediend. De juridische basis voor opname werd gevormd door een politierapport en een medische rapportage, waarin op geen enkele wijze wordt besproken om welk gedrag het nu precies ging. De nationale rechter had zelfstandig moeten vaststellen, aldus het Hof, in hoeverre klager een bedreiging vormde. Dat klager zelfstandig door de stad reisde om de bewuste jongen te zien is daartoe onvoldoende. Volgt een schending van artikel 5 lid 1 EVRM.

Er was geen sprake van een schending van artikel 5 EVRM in de Franse zaak Guelfucci. ${ }^{27}$ Het Hof verklaarde klaagster in deze zaak unaniem niet-ontvankelijk, waarmee de zaak werd gesloten. Klaagster, mevrouw Guelfucci, was in 1994 gedwongen opgenomen in een psychiatrisch ziekenhuis. Dit op verzoek van haar vader. Daarbij waren de benodigde geneeskundige verklaringen overgelegd om de opname te rechtvaardigen. Klaagster betwistte de rechtmatigheid van deze gedwongen opname, en was daarvoor op nationaal niveau gaan procederen. Klaagster was via zowel het bestuursrecht als het strafrecht opgekomen tegen haar vrijheidsbeneming.

Het Hof overwoog in het bijzonder dat in deze zaak was voldaan aan de criteria die bepalen of iemand kan worden aangeduid als een persoon met een 'geestesziekte' die vervolgens van zijn vrijheid kan worden beroofd. Uit de zaak komt niet naar voren
24 EHRM 28 november 2017, N. t. Roemenië, nr. 59152/08, ECLI:CE:ECHR:2017:1128JUD005915208.

25 EHRM 20 februari 2018, X t. Rusland, nr. 3150/15, ECLI:CE:ECHR:2018:0220JUD000315015, EHRC $2018 / 88$.
26 EHRM 24 oktober 1979, Winterwerp t. Nederland, nr. 6301/73, ECLI:CE:ECHR:1979:1024JUD000630173, NJ 1980/114, m.nt. E.A. Alkema.

27 EHRM 26 juli 2018, Guelfucci t. Frankrijk (ontv.besl.), nr. 31038/12, ECLI:CE:ECHR:2018:0703DEC003103812. 
dat er redenen zijn om hieraan te twijfelen. Er zijn dus geen aanleidingen om eraan te twijfelen dat sprake is geweest van een onrechtmatige vrijheidsberoving.

\section{- Gedwongen opname zonder voorafgaande} beoordeling van geestelijke gesteldheid

Zoals bekend ontvangt het Hof ieder jaar diverse klachten van personen die stellen dat zij onvrijwillig zijn opgenomen in een instelling zonder dat hun geestelijke gesteldheid vooraf door een ter zake deskundige ('medical expert') was beoordeeld. Een zo'n zaak, D.R. tegen Litouwen, ${ }^{28}$ haal ik bij wijze van voorbeeld aan. D.R. is een vrouw die meermaals vanwege haar psychische stoornissen opgenomen is geweest in psychiatrische instellingen. Nadat ze een traangasapparaat had aangeschaft, en gebruikt, om zich tegen buren te kunnen beschermen, wordt zij via een rechterlijke uitspraak gedwongen een psychiatrisch onderzoek te ondergaan. De klacht van D.R. richt zich tegen dit onderzoek, waarbij haar handen vanwege haar verzet werden geboeid, en de daaropvolgende gedwongen opname van één jaar. Het Hof stelt vast dat de Litouwse wetgeving niet duidelijk was met betrekking tot de vraag of was voorzien in de mogelijkheid om een persoon gedwongen op te nemen voor een gezondheidsonderzoek. Omdat de nationale autoriteiten hierover tegenstrijdige verklaringen geven aan het Hof, neemt het Hof aan dat een wettelijke basis ontbrak om D.R. voor onderzoeksdoeleinden onvrijwillig op te nemen, en dat er aldus was gehandeld in strijd met artikel 5 lid 1 EVRM. Het Hof stelt ook vast dat D.R. op basis van gebrekkige informatie gedwongen was opgenomen, waarbij bijvoorbeeld niet was gekeken naar de informatie die reeds over haar beschikbaar was en naar minder verstrekkende maatregelen dan een gedwongen opname. Het Hof stelt ook vast dat de rechterlijke uitspraken in deze zaken bijzonder mager zijn en weinig inzicht verschaffen in de overwegingen van de rechtbank. Volgt nogmaals een schending van artikel 5 lid 1

EHRM 26 juni 2018, D.R. t. Litouwen, nr. 691/15, ECLI:CE:ECHR:2018:0626JUD000069115.
EVRM. Het Hof kent klaagster een immateriële schadevergoeding toe van $€ 7.500$.

\subsection{Recht op een eerlijk proces (art. 6 EVRM)}

Het recht op een eerlijk proces, dat wordt beschermd door artikel 6 EVRM, is nauw verbonden aan het zojuist besproken recht op vrijheid en veiligheid. Het recht op een eerlijk proces legt verschillende verplichtingen op aan de autoriteiten, die ook van belang zijn in gezondheidsrechtelijke zaken.

\section{- Behandeling zaak door een onafhankelijk en onpartijdig gerecht}

Nauw verbonden aan het recht om een zaak te laten behandelen door een onafhankelijk en onpartijdig gerecht, is er het recht dat het gerecht zich laat informeren door onafhankelijke en onpartijdige deskundigen. Deze verplichting geldt ook voor bestuursorganen, zoals overheidsorganen die beslissen over de aanspraak op een socialezekerheidsuitkering of het recht op een rechtmatig verblijf. Burgers moeten erop kunnen vertrouwen dat is voldaan aan het beginsel van wapengelijkheid ('equality of arms'). De uitspraak van het Hof in de Sloveense zaak Korošec ${ }^{29}$ heeft in het Nederlandse bestuursrecht grote gevolgen gehad en is deze verslagperiode door het Hof nader gepreciseerd.

Die verduidelijking kwam in een nieuwe Sloveense zaak, de zaak Devinar. ${ }^{30}$ Mevrouw Devinar beklaagde zich erover dat er een besluit was genomen over de toekenning aan haar van een gehandicaptenuitkering op basis van opinies van een arts verbonden aan de Gehandicaptencommissie, en dat deze commissie en rechters hadden geweigerd een eigen onafhankelijke deskundige in te schakelen. Volgens klaagster was daarmee gehandeld in strijd met artikel 6 lid 1 EVRM.

29 EHRM 8 oktober 2015, Korošec t. Slovenië, nr. 77212/12, ECLI:CE:ECHR:2015:1008JUD007721212, AB 2016/167, m.nt. T. Barkhuysen en M. van Emmerik.

30 EHRM 22 mei 2018, Devinar t. Slovenië, nr. 28621/15, ECLI:CE:ECHR:2018:0522JUD002862115. 
Het Hof overweegt dat in dit soort zaken naar allerlei zaken moet worden gekeken. Het Hof heeft eerder uitgemaakt dat het EVRM er niet aan in de weg staat dat nationale rechters hun uitspraken baseren op deskundigenoordelen die ten grondslag liggen aan besluiten van gespecialiseerde lichamen in een poging een conflict te beslechten. Wat echter nodig is, is dat het uitgangspunt van neutraliteit van de zijde van de aangewezen deskundige wordt gerespecteerd, dat de gerechtelijke procedure voldoet aan het beginsel van hoor en wederhoor en dat wordt voldaan aan de eis van wapengelijkheid. In dit verband, overweegt het Hof, heeft het Hof eerder uitgemaakt dat indien er een deskundige wordt ingeschakeld die verbonden is aan hetzelfde bestuursorgaan dat het aangevallen besluit heeft genomen, er aanleiding kan zijn om de onafhankelijkheid en onpartijdigheid van de deskundige in twijfel te trekken. In de voorliggende situatie had de rechter naar alle feiten en omstandigheden gekeken. Het Hof erkent dat er twijfels kunnen zijn ontstaan bij klaagster over de onafhankelijkheid van de ingeschakelde adviserend arts, maar deze twijfels zijn in de voorliggende zaak niet ernstig genoeg om te kunnen spreken van een schending van artikel 6 lid 1 EVRM, omdat er geen aanleiding is om aan te nemen dat de artsen van de Gehandicaptencommissie onafhankelijkheid ontbeerden. De nationale rechter had onderkend dat dit gevaar bestond, maar benadrukte dat hiervan in de voorliggende situatie geen sprake was en dat het klaagster vrij stond een eigen deskundige aan te wijzen. Rechter Pinto de Albuquerque schreef een concurring opinion. Volgens hem was er in dit geval wel sprake van een schending van artikel 6 lid 1 EVRM.

\section{- Spoedige behandeling zaak}

Artikel 6 EVRM schrijft ook voor dat een zaak binnen een redelijke termijn moet worden beoordeeld door een gerecht. Over de naleving van dit recht waren afgelopen verslagperiode twee voor het gezondheidsrecht interessante zaken.
De Kroatische zaak Jurica ${ }^{31}$ betreft klachten van een vrouw die klachten ondervond na een middenooroperatie. Zij raakte zelfs verlamd aan de linkerkant van haar gezicht en ging toen met pensioen. Jurica stelde het ziekenhuis en de zorgverzekeraar aansprakelijk wegens nalatigheid. Na een procedure van ruim veertien jaar wijst het Kroatische Constitutionele Hof de vorderingen van klaagster af. Klaagster meent dat sprake is van een schending van artikel 6 EVRM wegen het overschrijden van de redelijke termijn. Klaagster meent daarnaast dat sprake is van een schending van artikel 8 EVRM omdat het krijgen van schadevergoeding vanwege medische nalatigheid alleen in theorie mogelijk is. Er ontbreekt in Kroatië immers een aparte rechtsgang voor medische schadeclaims.

Het Hof is met klaagster van oordeel dat de duur van de procedure onredelijk lang is geweest. Gedurende de periode van veertien jaar zijn er diverse langere perioden geweest van inactiviteit van de zijde van de overheid. Daarop stelt het Hof een schending van artikel 6 lid 1 EVRM vast. Daarentegen wijst het Hof de gestelde schending van artikel 8 EVRM van de hand. Niet kan worden volgehouden dat in Kroatië slechts een theoretische mogelijkheid bestaat om schadevergoeding te krijgen. Het EVRM verplicht niet tot het instellen van een aparte rechtsgang voor medische schadeclaims.

Soortgelijke omstandigheden deden zich voor in de Turkse zaak Günay. ${ }^{32}$ De dochter van klaagster was op zesjarige leeftijd overleden na een operatie in een ziekenhuis. De ouders vermoedden dat het overlijden van hun dochter het gevolg was van een medische fout, waarover zij niet waren geïnformeerd. Daarop volgen er allerlei juridische procedures, die in totaal zeven jaar duurden. Ook al blijkt uit die onderzoeken niet dat er sprake is geweest van een medische fout, het Hof constateert een schending van artikel 6 lid 1 EVRM. De Turkse autoriteiten hadden ervoor moeten zorgen dat er naar aanlei-

32 EHRM 20 februari 2018, Mehmet Günay en Güllü Günay t. Turkije, nr. 52797/08, ECLI:CE:ECHR: 2018:0220JUD005279708.
31 EHRM 2 mei 2017, Jurica t. Kroatië, nr. 30376/13, ECLI:CE:ECHR:2017:0502JUD003037613. 
ding van de klachten van klagers eerder was gezorgd voor uitsluitsel.

\subsection{Geen straf zonder wet (art. 7 EVRM)}

Het beginsel dat wetten niet met terugwerkende kracht mogen worden toegepast, zoals vastgelegd in artikel 7 EVRM, zijn voor het gezondheidsrecht doorgaans van ondergeschikt belang. Toch was er in de afgelopen verslagperiode één Duitse zaak die aandacht behoeft.

De zaak Ilnseher ${ }^{33}$ betreft een man die sinds 2008 in preventieve hechtenis verblijft. De hechtenis was opgelegd nadat de betrokkene een gevangenisstraf van tien jaar had uitgediend vanwege een seksueel gemotiveerde moord op een vrouw die aan het joggen was. Zijn detentie was steeds met terugwerkende kracht verlengd door rechters, op basis van psychiatrisch onderzoek waaruit bleek dat er een groot gevaar bestond op recidive. Klager stelde dat deze verlengingen strijdig waren met artikel 7 EVRM.

Het Hof oordeelt unaniem dat er geen sprake is van een schending van artikel 7 EVRM of een andere verdragsbepalingen. De Duitse rechters waren gerechtigd de detentie te verlengen omdat zij oordeelden dat klagers geestesziekte een vrijheidsontneming noodzakelijk maakte. Het Hof stelt daarbij vast dat tot detentie werd besloten met het oog op het behandelen van klager. De rechterlijke beslissingen kunnen daarom niet worden aangemerkt als 'straf' in de zin van artikel 6 EVRM.

\subsection{Recht op privé-, familie- en gezinsleven (art. 8 EVRM)}

Traditiegetrouw worden er onder de brede noemer van artikel 8 EVRM, in het bijzonder het recht op privé-, familie- en gezinsleven, door het Hof verschillende uitspraken gedaan die voor het gezondheidsrecht interessant kunnen zijn. Hoewel het Hof afgelopen verslagperiode in het kader van artikel 8 EVRM niet nader inging op de betekenis van het zelfbeschikkingsrecht, het recht op informa-

33 EHRM 2 februari 2017, Inseher t. Duitsland, nr. 27505/14, ECLI:CE:ECHR:2017:0202JUD001021112. tie over een behandeling en het verbod van dwangbehandeling, blijven er voldoende interessante zaken over.

\section{- Recht op schadevergoeding}

Afgelopen verslagperiode herhaalde het Hof zijn standpunt dat slachtoffers van medische fouten op grond van artikel 8 EVRM een vordering ter verkrijging van schadevergoeding moeten kunnen instellen. In de zaak Kurt ${ }^{34}$ houden de patiënt en haar ouders de Turkse autoriteiten verantwoordelijk voor schade na een operatie en het gebrek aan een effectief rechtsmiddel. Duru Kurt, geboren in 2003, werd in 2004 opgenomen in het ziekenhuis omdat zij ernstige hartproblemen bleek te hebben. In 2006 werd besloten dat zij aan haar hartkwalen moest worden geopereerd. Vader Kurt tekende daarvoor een verklaring van 'informed consent'. Tijdens de operatie trad een complicatie op. Daarom moest Duru in 2007 nogmaals worden geopereerd. Na deze operatie leed Duru aan oedeem, een hersenbloeding, leverproblemen en slecht werkende spieren. De ouders dienen daarop een klacht in tegen de behandelend artsen. De klachtencommissie van het ziekenhuis stelt vast dat er bij Duru thans sprake is van een hersenontsteking en dat zij voor $92 \%$ gehandicapt is geraakt. Daarop volgt een langdurige juridische strijd, waarop een van overheidswege aangewezen deskundige verklaart dat Duru een risicovolle operatie had ondergaan die in haar geval nodig was, dat daarbij vaak complicaties optreden en dat haar vader daarvoor toestemming had gegeven. Uiteindelijk worden de ouders door alle rechters in het ongelijk gesteld.

Het Hof oordeelt dat het deskundigenrapport op grond waarvan de nationale rechters hadden geoordeeld dat de aansprakelijk van de artsen moest worden afgewezen, onvoldoende duidelijkheid verschafte over de zaak waarover technisch inzicht was gevraagd - te weten of het handelen van de artsen had bijgedragen aan de schade. De deskundige verklaarde in zijn rapport alleen dat de artsen geen fou-

34 EHRM 6 juni 2017, Erdinç Kurt e.a. t. Turkije, nr. 50772/11, ECLI:CE:ECHR:2017:0606JUD005077211, EHRC 2017/144, m.nt. A.C. Hendriks. 
ten hadden gemaakt, maar gaf niet aan hoe de operatie was verlopen en hoe een en ander verder was verlopen. Het Hof oordeelt daarop dat klagers onvoldoende voordeel hadden gehad van een gepaste juridische reactie die voldeed aan de plicht om Duru Kurts recht op lichamelijke integriteit te beschermen. Het Hof kent klagers daarop een immateriële schadevergoeding toe van $€ 7.500$ plus een proceskostenvergoeding.

\section{- Recht op bescherming van medische persoonsgegevens}

Artikel 8 EVRM gebiedt verdragsstaten om zorgvuldig om te gaan met medische persoonsgegevens en kent individuele personen daarbij een aantal rechten toe. Over de precieze betekenis van die rechten heeft het Hof afgelopen verslagperiode in een viertal zaken geoordeeld.

De eerste zaak betreft de Oekraïense zaak Surikoy. ${ }^{35}$ Het Hof was gevraagd te oordelen over het niet toekennen van een promotie omdat de betrokkene in het verleden was afgekeurd voor het vervullen van militaire dienst vanwege de bij hem bestaande psychische gezondheidsproblemen. Klager, de heer Surikoy, werkte sinds 1990 bij de staatsuitgeverij Tavrida. In 1997 had klager zijn directeur om een promotie gevraagd. Omdat hij geen reactie ontving, verzocht hij in 2000 nogmaals om een promotie, die vervolgens werd geweigerd. Daarop richtte klager zich tot de rechtbank. Zijn werkgever motiveerde de weigering onder verwijzing naar klagers psychische geschiktheid, in het bijzonder de omstandigheid dat hij in 1981 was afgekeurd voor militaire dienst. De rechtbank oordeelde dat werkgevers een discretionaire bevoegdheid toekomt om zelf inkleuring te geven aan het promotiebeleid. Dit oordeel hield stand in hoger beroep. Klager laat zich daarop medisch keuren en krijgt een medische verklaring, ondertekend door zes medisch specialisten, waaruit zijn geschiktheid voor de functie blijkt. Dat verandert niets aan zijn situatie. Tussen 2000 en 2006 was klager verwikkeld in civiele procedures tegen zijn 42788/06, ECLI:CE:ECHR:2017:0126JUD004278806. werkgever vanwege het vermeende illegaal verwerken van medische gegevens over hem. Hij stelde voorts dat de afkeuring voor militaire dienst onvoldoende specifiek was en hij meende dat, indien zijn werkgever twijfels had over zijn medische geschiktheid, er gevraagd had moeten worden naar een actuele medische beoordeling. Ook bij deze procedures werd klager op nationaal niveau in het ongelijk gesteld.

In Straatsburg krijgt klager wel gelijk. Hij had gesteld dat zijn werkgever willekeurig gevoelige medische persoonsgegevens had verzameld, opgeslagen en gebruikt, en deze gegevens vervolgens ook openbaar had gemaakt, in strijd met artikel 8 EVRM, en dat de nationale rechter had geweigerd aandacht te besteden aan belangrijke door hem naar voren gebrachte klachten, in strijd met artikel 6 EVRM. Het Hof is bereid aan te nemen dat het verwerken van de op klager betrekking hebbende medische persoonsgegevens een basis had in de wet. Het Hof tekent daarbij aan dat Oekraïne ten tijde van dit geschil geen partij was bij het Verdrag inzake gegevensbescherming van de Raad van Europa. Het Hof concludeert evenwel dat de nationale wetgeving, zoals uitgelegd door de nationale rechter, het opslaan van medische persoonsgegevens voor een heel lange periode toestaat en eveneens toestaat dat deze gegevens worden verstrekt en gebruikt voor doelen die niet gerelateerd zijn aan het doel waarvoor zij oorspronkelijk waren verkregen. Het Hof ziet geen rechtvaardiging voor deze vormen van verwerken en concludeert tot schending van artikel 8 EVRM. Het Hof stelt ook een schending vast van artikel 6 lid 1 EVRM omdat de nationale rechters geen redenen hadden gegeven waarom zij de klachten van klager niet in behandeling hadden genomen.

De Franse zaak Aycaguer ${ }^{36}$ is de tweede zaak waarin het gebruik van medische gegevens aan de orde is. Klager, Jean-Michel Aycaguer, had in 2008 deelgenomen aan een protestbijeenkomst georganiseerd door een boerenvakbond en een organisatie van

36 EHRM 22 juni 2017, Aycaguer t. Frankrijk, nr. 8806/12, ECLI:CE:ECHR:2017:0622JUD000880612, EHRC $2017 / 160$. 
landeigenaren. Aan het eind van de bijeenkomst waren er ongeregeldheden ontstaan, waarbij demonstranten en de politie met elkaar op de vuist waren gegaan. Aycaguer werd vervolgens in voorlopige hechtenis gesteld. Hij werd beschuldigd van openbare geweldpleging waarvoor hij een voorlopige gevangenisstraf kreeg van twee maanden. Eind 2008 werd Aycaguer door de openbaar aanklager bevolen om DNA-materiaal af te staan onder verwijzing naar artikelen in het Franse wetboek van strafvordering. In mei 2009 werd hij opgeroepen te verschijnen voor de rechter omdat hij geen gehoor had gegeven aan het verschijningsbevel. De rechtbank legde Aycaguer een boete op van $€ 500$, een straf die tot aan de hoogste rechter in stand werd gelaten.

Aycaguer stelde in Straatsburg dat Frankrijk zijn recht op respect van zijn privéleven had geschonden (artikel 8 EVRM) doordat hij werd gedwongen om een genetisch monster af te staan om opgenomen te worden in de nationale DNA-databank (FNAEG) en dat hij als gevolg van de weigering strafrechtelijk was veroordeeld. Het Hof stelt vast dat het enkele feit dat persoonlijke gegevens in een databank worden opgenomen een inbreuk op het recht op privéleven oplevert. Het Hof erkent het belang van databanken ter bescherming van de bevolking. Databanken kunnen de autoriteiten helpen op effectieve wijze strafbare feiten te bestrijden en te helpen voorkomen, in het bijzonder zedendelicten. Het Hof heeft ervan kennis genomen dat Aycaguer tot nu toe niet in de databank is opgenomen, omdat hij medewerking aan het onderzoek weigerde. Hoewel de inbreuk op het privéleven van veroordeelden was voorgeschreven bij wet en een legitieme doelstelling dient, wijst het Hof er ook op dat de opslag van DNA van strafrechtelijk veroordeelden volgens de wet maximaal veertig jaar kan duren. De Franse regering had overwogen dat de duur van de opslag afhankelijk zou zijn van de ernst van het gepleegde strafbare feit. Het Hof stelt evenwel vast dat er nooit een uitwerking van dit beginsel heeft plaatsgevonden, met als gevolg dat DNA-materiaal in de praktijk altijd voor de maximale termijn van veertig jaar wordt bewaard. Het Hof wijst er ook op dat het Franse Grondwettelijke Hof op 16 september 2010 had beslist dat de in het geding zijnde wettelijke bepalingen niet in strijd zijn met de Franse Grondwet, zolang onder meer de duur van de opslag afhankelijk wordt gemaakt van de aard en de ernst van het gepleegde strafbare feit. Het Hof constateert dat de Franse autoriteiten nooit uitvoering hebben gegeven aan deze opdracht om de duur van de opslag te differentiëren. In de zaak van Aycaguer had het strafbare feit plaatsgevonden in de context van een politiek dispuut waarbij vakbonden waren betrokken. De strafbare feiten die hierbij hadden plaatsgevonden waren fundamenteel anders dan bij zedendelicten, terroristische activiteiten, mensenhandel of misdaden tegen de menselijkheid. Alleen personen die een onvoorwaardelijke straf opgelegd hadden gekregen konden verzoeken om de vernietiging van DNA-materiaal, niet personen die een voorwaardelijke straf hadden gekregen, zoals Aycaguer. Het Hof concludeert daarom dat de huidige wetgeving onvoldoende bescherming biedt aan personen van wie materiaal wordt opgenomen in de DNA-databank. Er had geen redelijke belangenafweging plaatsgevonden en de nationale autoriteiten hadden de hun toekomende beleidsruimte ('margin of appreciation') overschreden. De veroordeling van Aycaguer door niet mee te werken aan het afstaan van DNA-materiaal levert daarom een disproportionele inbreuk op van zijn respect op bescherming van zijn privéleven en een schending van artikel 8 EVRM.

Hoe anders lagen de feiten in de uit Bulgarije afkomstige zaak Yonchev, ${ }^{37}$ de derde zaak over het gebruik van medische gegevens. Klager, een politieman, had jarenlang deelgenomen aan internationale politiemissies. In 2001 wil hij wederom deelnemen aan zo'n missie. Daarvoor moet hij een psychologisch onderzoek ondergaan. Omdat de uitkomst van dit onderzoek negatief uitviel voor klager, wordt hij niet geselecteerd voor de internationale missie. Klager verzoekt daarop meermaals inzage in zijn dossier, in het bijzonder de uitkomsten van het psychologisch onderzoek. De nationale autoriteiten menen

37 EHRM 7 december 2017, Yonchev t. Bulgarije, nr. 12504/09, ECLI:CE:ECHR:2017:1207JUD001250409. 
dat klager in kennis is gesteld van de uitkomsten van het onderzoek, maar verstrekken klager geen inzage in of kopie van het dossier omdat dat als staatsgeheim is aangemerkt.

Het Hof gaat niet mee in het verweer van de nationale autoriteiten. Uit de voorgaande procedures is nooit gesteld of anderszins gebleken dat het dossier van klager als staatsgeheim moest worden beschouwd. Evenmin was duidelijk naar voren gebracht door de autoriteiten op welke onderdelen van het dossier dit criterium van toepassing was. Het Hof stelt daarop een schending vast van artikel 8 EVRM en kent klager een immateriële schadevergoeding toe van $€ 1.500$, naast vergoeding van de door hem gemaakte kosten.

Van een geheel andere orde waren de klachten van klaagster in de Litouwse zaak Mockuté. ${ }^{38}$ Klaagster was in de periode 1992-2002 regelmatig behandeld wegens psychiatrische stoornissen, waaronder depressies en paranoia. In 2003 had betrokkene zich aangesloten bij het Ojas Meditatie Centrum, een afdeling van de religieuze beweging Osho. Volgens klaagster gaf haar dit innerlijke rust. Als zij enige maanden later toch in een crisissituatie belandt, wordt zij gedwongen opgenomen in een psychiatrisch ziekenhuis waar zij 52 dagen verblijft. In die periode wordt op televisie een programma uitgezonden over het Ojas Meditatie Centrum waarin klaagsters arts, moeder en zuster worden geïnterviewd. Klaagster wordt niet bij naam genoemd, maar krijgt de naam 'Violetta'. Klaagster start vervolgens een gerechtelijke procedure. $\mathrm{Zij}$ wordt in het gelijk gesteld aangaande de onrechtmatige vrijheidsbeneming, maar de hoogste nationale rechter oordeelt dat het beroepsgeheim en de privacy van klaagster niet waren geschonden, hoewel klaagster meent dat uit het televisieprogramma herleidbaar was dat het om haar ging.

Het Hof concludeert allereerst dat er sprake was geweest van een schending van artikel 8 EVRM. Vaststond dat een arts van het psychiatrisch zieken- huis gevoelige vertrouwelijke informatie had gedeeld met journalisten en klaagsters moeder, zonder toestemming van klaagster. Dit was in strijd met internationale en nationale regels inzake gezondheidsgegevens en privacy.

Klaagster had daarnaast gesteld dat zij in het psychiatrisch ziekenhuis niet in staat was gesteld haar godsdienst te beleven. Het Hof vindt dit in het algemeen geen zaak om over te oordelen, maar een zaak voor de nationale rechter, maar concludeert in de voorliggende zaak dat niettemin sprake is geweest van het recht op vrijheid van godsdienst (art. 9 EVRM). Klaagster was namelijk onrechtmatig voor meer dan vijftig dagen opgenomen geweest, grotendeels onder een strikt regime, waarin zij niet kon mediteren en evenmin naar het Ojas Medicatie Centrum kon. Bovendien stond vast dat de artsen hadden getracht haar te corrigeren en over te halen haar godsdienst te verlaten. Daarom concludeert het Hof ook tot schending van artikel 9 EVRM.

\section{- Rechten op informatie over overledenen}

Het Hof lijkt afgelopen jaren ook steeds meer zaken te behandelen waarin nabestaanden erover klagen dat zij door de autoriteiten niet goed zijn geïnformeerd over het overlijden van een familielid. Afgelopen verslagperiode heeft het Hof daarover twee opvallende uitspraken gedaan.

In de zaak Lozovyye, ${ }^{39}$ afkomstig uit Rusland, beklaagden ouders zich erover dat zij door de politie niet waren geïnformeerd over de dood van hun zoon M. na een handgemeen met O. Dit terwijl de openbaar aanklager de politie daartoe opdracht had gegeven. Daarop werd M. van overheidswege begraven nog voordat klagers wisten dat hun zoon was overleden. Toen klagers uiteindelijk weet kregen van de dood van M. zijn zij betrokken geweest in de strafprocedure tegen $\mathrm{O}$. en hebben zij een herbegrafenis voor M. georganiseerd. O. is uiteindelijk veroordeeld wegens moord.

39 EHRM 24 april 2018, Lozovyye t. Rusland, nr. 4587/09, ECLI:CE:ECHR:2018:0424JUD000458709, EHRC 2018/141, m.nt. A.C. Hendriks. 
De zaak die aan het Hof is voorgelegd heeft betrekking op de schadevergoedingsprocedure die klagers hebben ingesteld tegen de staat. Klagers eisten materiële schadevergoeding vanwege de herbegrafenis van M., en immateriële schadeloosstelling in verband met het gebrek aan informatie door de politie over het overlijden van M. Deze claims werden op nationaal niveau afgewezen, omdat het handelen van de politie niet onrechtmatig was geweest, aldus de nationale rechter.

Het Hof onderzoekt de klachten van klagers onder artikel 8 EVRM, hoewel klagers hun klacht hadden gebaseerd op artikel 6 en 13 EVRM. Het Hof stelt voorop dat verschillende begrafenisrituelen volgens zijn eerdere rechtspraak binnen het bereik van artikel 8 EVRM vallen. In het licht van zijn rechtspraak over het recht op informatie over het privé- en gezinsleven, samen met de rechtspraak over de toepasselijkheid van artikel 8 EVRM over de mogelijkheid van mensen om de begrafenis van een overleden familielid bij te kunnen wonen, overweegt het Hof dat het recht van klagers op respect van hun privé- en gezinsleven is aangetast doordat de staat heeft nagelaten hen te informeren over de dood van hun zoon voordat hij was begraven. Artikel 8 EVRM is dan ook van toepassing. Vervolgens is de vraag of er in dit geval een positieve verplichting bestond voor de staat om klagers deze informatie te verstrekken. Weliswaar verplicht het Russische recht daartoe niet expliciet, maar in het kader van de nationale procedure is er een tussenvonnis geweest waarin de rechtbank heeft vastgesteld dat de interne procedureregels waren geschonden. Daarnaast is van belang dat er verschillende wegen waren geweest om de nabestaanden en hun adresgegevens te achterhalen, terwijl er geen verklaring is gegeven waarom die mogelijkheden niet zijn benut. Volgt een schending van artikel 8 EVRM, waarbij het Hof klagers naast een onkostenvergoeding $€ 10.000$ immateriële schadevergoeding toekent.
In de tweede zaak over het recht op informatie over overledenen, de Turkse zaak Özer, ${ }^{40}$ speelden soortgelijke vragen. Het feitencomplex lag echter geheel anders. Klagers in deze zaak, een broer en een zus, waren hun beider kinderen verloren als gevolg van geweld door militairen. Het werd hen vervolgens niet toegestaan om hun kinderen te begraven vanwege de onrust in de buurt, onrust die door de PKK zou worden veroorzaakt. Uiteindelijk hebben de lokale autoriteiten de kinderen van klagers begraven, zonder religieuze ceremonie. De klagers hebben zich hierover tevergeefs op nationaal niveau beklaagd.

Het Hof oordeelt dat het beslagleggen op de lijken van de kinderen in combinatie met het weigeren toestemming te geven voor een begrafenis een schending oplevert van artikel 8 EVRM. Het Hof oordeelt dat er geen redelijk evenwicht ('fair balance') bestond tussen het recht op privé- en gezinsleven en het doel van openbare veiligheid, het voorkomen van onrust en de bescherming van de rechten en vrijheden van anderen. Ook in deze zaak kent het Hof klagers, naast een vergoeding van de door hen gemaakte kosten, een immateriële schadevergoeding toe van $€ 10.000$.

\section{- Recht op cannabis}

De ontvankelijkheidsbeslissing van het Hof in de Hongaarse zaak A.M. en A.K. ${ }^{41}$ ging over het recht op cannabis in relatie tot de persoonlijke autonomie van klagers. Klagers hebben ernstige ziekten, waaronder multiple sclerose. Zij zijn ervan overtuigd dat op cannabis gebaseerde medicatie de bij hen bestaande pijn kan verlichten. In Hongarije zelf wordt dit soort medicatie niet geproduceerd, maar onder het Hongaarse recht is het mogelijk om individuele toestemming te krijgen voor de import van bepaalde niet in Hongarije beschikbare medicatie. De patiënt moet daarvoor een recept van een dokter

40 EHRM 29 mei 2018, Gülbahar Özer en Yusuf Özer t. Turkije, nr. 64406/09, ECLI:CE:ECHR: 2018:0529JUD006440609.

41 EHRM 4 april 2017, A.M. en A.K. t. Hongarije (ontv.besl.), nr. 21320/15, 35837/15, ECLI:CE:ECHR: 2017:0404DEC002132015, EHRC 2017/149. 
in Hongarije overleggen aan het Nationaal Instituut voor Farmacie en Voeding (NIPN). Klagers vrezen echter dat vanwege de bestaande drugswetgeving in Hongarije artsen niet zullen willen meewerken aan het uitschrijven van zo'n recept. De mogelijke vervolging wegens drugsbezit heeft volgens klagers een 'chilling effect' tot gevolg bij de artsen.

Het EHRM stelt in zijn ontvankelijkheidsbeslissing voorop dat er in Hongarije op zichzelf wel een legale weg beschikbaar is om dit soort medicatie te kunnen verkrijgen, maar ook dat Hongarije wel moet voorkomen dat de bepalingen over deze medicatie zodanig zijn geformuleerd dat daarvan daadwerkelijk een 'chilling effect' uitgaat, terwijl de individuele belangen van een patiënt dit soort medicatie wel vereisen. Het Hof acht echter onvoldoende aangetoond dat de klagers in deze zaak de medicatie werkelijk nodig hadden of dat zij zelfs maar met hun artsen hadden gesproken over de mogelijkheid om deze medicatie te importeren. Ook is niet gebleken dat enige arts in Hongarije ooit is vervolgd vanwege het voorschrijven van cannabisgebaseerde medicatie, of dit heeft geweigerd uit vrees voor zo'n vervolging. De klacht is volgens het Hof daarom kennelijk ongegrond.

\section{- Huiszoeking wegens illegale geneesmiddelen}

Omdat artikel 8 EVRM ook bepaalt dat iedereen recht heeft op recht op respect voor de woning, wil ik de Letse zaak Bože $e^{42}$ aanhalen om te illustreren dat dit aspect van artikel 8 EVRM ook relevant kan zijn voor het gezondheidsrecht. Deze zaak had betrekking op het doorzoeken van de woning van klager en de inbeslagname van voorwerpen in het kader van een undercover politieactie. De politie was in 2004 tot deze maatregelen overgegaan in het kader van de verdenkingen tegen klager dat hij via internet geneesmiddelen tegen HIV, hepatitis en kanker zou verkopen die in Letland niet waren toegelaten. De undercoveragenten hadden met klager afgesproken zich bij de woning van klager te verzamelen. Zij kochten sommige van de geneesmiddelen. Zij ver-

EHRM 18 mei 2017, Bože t. Letland, nr. 40927/05, ECLI:CE:ECHR:2017:0518JUD004092705. telden klager daarop direct over hun actie, en gingen vervolgens over tot huiszoeking. Klager werd verteld dat de actie in overeenstemming was met het Letse wetboek van strafvordering. De huiszoeking duurde vijf uur en resulteerde erin dat diverse voorwerpen in beslag werden genomen, waaronder klagers computer en de harde schijf. Klager kreeg daarop een bestuurlijke boete wegens het bereiden en het verkopen van niet-toegelaten geneesmiddelen. Ondertussen had klager diverse zaken aangespannen, stellende dat de politie-inspectie neerkwam op een huiszoeking die niet in overeenstemming met de relevante wettelijke bepalingen was uitgevoerd. Die klachten werden op nationaal niveau allemaal afgewezen, waarbij nauwelijks werd ingegaan op klagers inhoudelijke klachten.

Het Hof constateert dat de huiszoeking diverse gebreken vertoonde. Het Hof stelt vast dat de juridische basis van de huiszoeking achteraf is veranderd. De nationale autoriteiten hebben ook niet uitgezocht waarom er aanvankelijk geen goede juridische basis was voor de huiszoeking. De bestuursrechter had tot slot geen betekenisvolle toets uitgevoerd met betrekking tot de rechtmatigheid van de actie en de omvang van de beslaglegging. Daarop concludeert het Hof tot schending van artikel 8 EVRM. Klager had bijna $€ 146$ miljoen immateriële schadevergoeding geclaimd. Het Hof gaat daarin niet mee en volstaat met een vergoeding van $€ 3.000$.

\section{- Procedurele verplichtingen}

In de Turkse gezondheidszorg is veel mis. En er gaat veel tijd gemoeid met het onderzoeken van mogelijke fouten en de behandeling van schadeclaims. ${ }^{43}$ Zo ook in de zaak Eryiğit, ${ }^{44}$ een zaak waarin het Hof een procedurele schending van artikel 8 EVRM vaststelde.

De klacht heeft betrekking op een, volgens klagers, verkeerde prenatale diagnose. In 1997 - dus ruim twintig jaar geleden - werd de zwangere mevrouw Eryiğit overgebracht naar het Süleymaniye Zieken-

43 EHRM 27 maart 2018, Ibrahim Keskin t. Turkije, nr. 10491/12, ECLI:CE:ECHR:2018:0327JUD001049112.

44 EHRM 10 april 2018, Eryiğit t. Turkije, nr. 18356/11, ECLI:CE:ECHR:2018:0410JUD001835611. 
huis. Volgens het daar uitgevoerde prenatale onderzoek was zij in verwachting van een tweeling. $\mathrm{Zij}$ werd vervolgens overgebracht naar het Şişli Etfal Ziekenhuis, waar artsen op basis van een echografisch onderzoek tot dezelfde conclusie kwamen. Daarop werd klaagster verwezen naar het Zeynep Kamil Ziekenhuis. De volgende dag beviel klaagster, aldaar, van een kind, maar niet van twee kinderen. Samen met andere familieleden deed klaagster daarop aangifte van het verdwijnen van een kind. De openbaar aanklager sloot uiteindelijk het strafrechtelijk onderzoek, omdat er sprake was geweest van een verkeerde diagnose. Dat zou het gevolg zijn geweest van het overgewicht van klaagster. Er was nooit sprake geweest van een zwangerschap van een tweeling. De klachten van klaagster en haar familieleden tegen dit besluit werden in hoger beroep ongegrond verklaard, alsook door de hoogste bestuursrechter, al kende die mevrouw Eryiğit schadevergoeding toe.

In Straatsburg stelden klaagster en haar familie dat zij niet helemaal financieel waren gecompenseerd voor de schade die zij hadden geleden. Zie stelden ook dat het onderzoek niet spoedig en effectief was geweest. Het Hof kent hun $€ 3.000$ immateriële schadevergoeding toe vanwege het niet naleven van de procedureverplichtingen door Turkije op grond van artikel 8 lid 2 EVRM. Klagers komen daarnaast in aanmerking voor vergoeding van de door hen gemaakte proceskosten.

\subsection{Recht op vrijheid van meningsuiting (art. 10 EVRM)}

Journalisten spelen in een democratische rechtsstaat een belangrijke rol om het publiek over bepaalde zaken te informeren, maar de wijze waarop journalisten de door hen vergaarde kennis publiceren kan strijd opleveren met de rechten van personen, in het bijzonder het recht op privéleven (artikel 8 EVRM). In zo'n situatie is dan de vraag of op juiste wijze gebruik is gemaakt van de vrijheid van meningsuiting of dat aan andere rechten meer belang moet worden gehecht.
Dit dilemma deed zich voor in de Deense zaak Frisk en Jensen. ${ }^{45}$ In deze zaak hadden twee journalisten, werkzaam voor twee nationale televisiezenders, een geldboete gekregen van ongeveer $€ 1.340$ per persoon voor het leveren van kritiek op de kankerbehandeling zoals die werd aangeboden in het Universitair Ziekenhuis te Kopenhagen. Een van de klagers had een televisieprogramma gemaakt - aangekondigd als een documentaire - met de titel 'When the doctor knows best'. Dit werd in 2008 uitgezonden. Het programma trok ruim een half miljoen kijkers. In het programma werd verslag gedaan van de behandeling van patiënten met pleuraal mesothelioom in het eerder genoemde ziekenhuis onder leiding van arts S. Het programma richtte zich op twee typen chemotherapie bij pleuraal mesothelioom, namelijk Alimta en Vinorelbine. S. gebruikte voor het ziekenhuis een combinatie van Vinorelbine en Cisplatine of Carboplatine. De suggestie die in het programma werd gedaan, is dat deze combinatie minder succesvol is dan de combinatie van Alimta en Cisplatine en dat $S$. de verkeerde keuze had gemaakt door deze combinatie niet voor te schrijven. Uit het onderzoek dat de klager had verricht, bleek echter dat Alimta-gebaseerde behandelingen niet effectiever zouden zijn; beide combinaties waren ongeveer even effectief. Gelet op de gewekte suggestie hebben het universiteitsziekenhuis en $\mathrm{S}$. een smaadklacht tegen de directeur van het televisiestation en de twee klagers ingediend. De rechtbank veroordeelde de klagers uiteindelijk inderdaad wegens smaad tot betaling van een boete en tot nietigverklaring van de litigieuze uitingen. Klagers stelden hiertegen beroep in bij het Hof.

Het Hof onderzoekt allereerst of het ziekenhuis zelf wel slachtoffer kon zijn van smaad, nu het geen natuurlijk persoon is. Het constateert echter dat de beschuldigingen in het programma duidelijk het ziekenhuis in een kwaad daglicht stelden. Bovendien kan het ziekenhuis hier eerder worden gezien als een vertegenwoordiger van ongenoemde leden van het management en het personeel, die ook

45 EHRM 5 december 2017, Frisk en Jensen t. Denemarken, nr. $\quad 19657 / 12$ ECLI:CE:ECHR: 2017:1205JUD001965712, EHRC 2018/42. 
nadeel hadden van de beschuldigingen. De vraag is dan of de nationale rechters een redelijke afweging hebben gemaakt tussen het recht op bescherming van de reputatie enerzijds en de vrijheid van meningsuiting anderzijds. Op basis van de Von Hannover-criteria, ${ }^{46}$ over de afweging van vrijheid van meningsuiting versus privacy, overweegt het Hof allereerst dat de kwestie duidelijk een algemeen belang betrof, zoals ook is erkend door de nationale rechter. De kritiek richtte zich bovendien op publieke figuren. Het ziekenhuis is immers een publieke instelling, zoals de nationale rechter eveneens heeft vermeld. De nationale rechter uitgebreid citerend overweegt het Hof vervolgens dat voldoende is komen vast te staan dat het programma de reputatie van het ziekenhuis ernstig aantastte. Dit geldt temeer nu het programma door de publieke omroep is uitgezonden en is gepresenteerd als 'documentaire', zodat de kijkers konden verwachten dat zij de waarheid te horen zouden krijgen. Het Hof stelt verder vast dat voldoende aannemelijk is dat de twee therapieën waar het om gaat in effectiviteit vergelijkbaar zijn, zodat er geen goede grond was om de goede trouw van het ziekenhuis in twijfel te trekken. Qua onderzoek hebben de journalisten zeer goed en uitgebreid werk gedaan en het ziekenhuis heeft daaraan ook steeds loyaal meegewerkt. Het onderzoek is echter duidelijk op een onjuiste manier gepresenteerd, zoals de nationale rechter opnieuw heeft opgemerkt. Ten slotte is de sanctie vrij zwaar omdat het gaat om een strafrechtelijke veroordeling, maar in de gegeven omstandigheden is dit niet onredelijk en gaat er geen 'chilling effect' van uit. Geen schending van artikel 10 EVRM.

\subsection{Verbod van discriminatie (art. 14 EVRM)}

Deze kroniek sluit ik af met twee zaken waarin het verbod van discriminatie centraal staat.

EHRM 24 juni 2004, Von Hannover t. Duitsland, nr. 59320/00, ECLI:CE:ECHR:2004:0624JUD005932000, NJ 2005/22, m.nt. E.J. Dommering, AB 2005/1, m.nt. R. Nehmelman, EHRC 2004/79, m.nt. J.H. Gerards.
De eerste zaak is afkomstig uit Frankrijk en was ingediend door mevrouw Saumier. ${ }^{47}$ Klaagster had in het verleden twee jaar gewerkt bij een laboratorium met stoffen die ervoor hadden gezorgd dat zich bij haar op zeer jonge leeftijd de ziekte van Parkinson had ontwikkeld. Als gevolg daarvan is ze arbeidsongeschikt geraakt. In verband daarmee is aan klaagster een arbeidsongeschiktheidsuitkering toegekend op basis van een beperking van $70 \%$. Omdat de rechter aannam dat de werkgever volledig verantwoordelijk was voor de beroepsziekte, is dat percentage vervolgens verhoogd naar $100 \%$.

Daarnaast heeft klaagster verzocht om een immateriële schadevergoeding. Deze vergoeding is gedeeltelijk toegewezen. Haar schadeclaim wegens geleden en te lijden inkomensverlies en een aantal aanverwante eisen werden echter afgewezen. De wettelijke regeling inzake beroepsziekten kent een beperkte (forfaitaire) schadevergoeding en sluit een beroep op schadevergoeding volgens het burgerlijk recht uit.

Klaagster stelt in Straatsburg dat zij door deze berekeningswijze feitelijk minder schade vergoed heeft gekregen dan het geval zou zijn wanneer een beroepsziekte als onrechtmatige daad was aangemerkt. Bij een onrechtmatige daad is immers het toekennen van volledige schadevergoeding het uitgangspunt. Het Hof verwerpt het verweer van Frankrijk dat er geen schending van het eigendomsrecht aan de orde is. Volgens Frankrijk bestaat er immers niet zoiets als een recht op volledige schadevergoeding bij onrechtmatige daden van anderen. Het Hof wijst op de rechtspraak die inhoudt dat aan het commune aansprakelijkheidsrecht de gerechtvaardigde verwachting op schadeloosstelling kan worden ontleend en dat die verwachting als eigendom kan kwalificeren. De wettelijke regeling inzake beroepsziekten in Frankrijk beperkt het recht op schadeloosstelling. Er is hier dan ook een aanspraak aanwezig die kan worden gekwalificeerd als eigendom in de zin van artikel 1 Eerste Protocol (EP) van het EVRM.

47 EHRM 12 januari 2017, Saumier t. Frankrijk, nr. 74734/14, ECLI:CE:ECHR:2017:0112JUD007473414, EHRC 2017/69, m.nt. B. Barentsen. 
Het Hof stelt vast dat de Franse regeling inzake beroepsziekten leidt tot automatische vergoeding van arbeidsongeschiktheid, ongeacht de eventuele aansprakelijkheid van de werkgever. Wel kan deze vergoeding worden verhoogd bij een ernstige mate van verwijtbaarheid ('faute inexcusable') van de werkgever. Deze regeling levert een te verwachten aanspraak op op een geldelijke uitkering die voldoende zeker is om van gerechtvaardigde verwachtingen in de zin van artikel 1 EP te spreken. Die bepaling verplicht niet tot het in het leven roepen van een socialezekerheidsregeling. Bij de uitvoering en inrichting van bestaande regelingen mag echter niet worden gediscrimineerd.

Op het eerste gezicht zijn er overeenkomsten tussen slachtoffers van letselschade in de werksfeer en slachtoffers die in een andere context letselschade hebben opgelopen. Naar het oordeel van het Hof is echter geen sprake van ongelijke behandeling van gelijke gevallen. De regeling die op klaagsters situatie van toepassing is, heeft immers een specifiek karakter en is primair gebaseerd op het uitgangspunt van solidariteit. De regeling wordt automatisch toegepast; de werknemer hoeft niet in een procedure aan te tonen dat zijn werkgever tekort is geschoten. Op de andere situaties waarnaar klaagster verwijst was een andere regeling van toepassing, die niet voldoende vergelijkbaar is. De relatie werkgever-werknemer is een contractuele, waarbij de werknemer onder het gezag van de wederpartij staat. Die kenmerken ontbreken bij een commune onrechtmatige daad. Volgt afwijzing van het Hof van de stelling van klaagster dat jegens haar artikel 14 EVRM was geschonden in samenhang met artikel $1 \mathrm{EP}$.

De tweede zaak waarin een klaagster meende dat er jegens haar was gediscrimineerd betrof de Portugese zaak Carvalho Pinto de Sousa Morais. ${ }^{48}$ Klaagster is een vrouw die op 50-jarige leeftijd was geopereerd vanwege een ontsteking in het vulvagebied (abcessus

48 EHRM 25 juli 2017, Carvalho Pinto de Sousa Morais t. Portugal, nr. 17484/15, ECLI:CE:ECHR: 2017:0725JUD001748415, EHRC 2017/162, m.nt. A.C. Hendriks. glandulae Bartholini). Tijdens de operatie, waarbij de klieren van Bartholini waren verwijderd, had de behandelend arts ook een zenuw beschadigd. Klaagster heeft sindsdien ernstige pijnklachten, is incontinent en kan niet genieten van een seksueel leven.

De nationale rechter had vastgesteld dat de behandelend arts roekeloos te werk was gegaan en dat de operatie niet volgens de regelen der kunst was uitgevoerd. Naast materiële schadevergoeding was aan klaagster immateriële schadevergoeding toegekend. Daarop was het ziekenhuis van de behandelend arts in hoger beroep gegaan. De hoogste nationale bestuursrechter ('Supremo Tribunal Administrativo') besloot in hoger beroep de eerder toegekende immateriële schadevergoeding en de vergoeding voor hulp in de huishouding ongeveer te halveren. Daarbij overwoog de rechter onder meer dat 'niet moest worden vergeten dat klaagster op het moment van de operatie al 50 jaar oud was en twee kinderen had, dat het een leeftijd is waarop seks niet langer zo belangrijk is als op jongere leeftijd en dat het seksleven significant vermindert met de jaren'.

Klaagster stelt in het bijzonder dat de beslissing om de aan haar toekomende letselschadevergoeding te verlagen discriminatoir is, omdat de rechter voorbij was gegaan aan het belang van een seksueel leven voor een vrouw. Het Hof stelt vast dat klaagsters leeftijd en geslacht kennelijk van doorslaggevend belang waren geweest voor de definitieve beslissing om de toe te kennen schadevergoeding te verlagen. De beslissing was bovendien gebaseerd op de algemene veronderstelling dat seksualiteit voor een 50jarige vrouw en moeder van twee kinderen minder belangrijk is dan voor een jongere persoon. In de optiek van het Hof wijzen dit soort overwegingen op vooroordelen binnen de Portugese rechterlijke macht. Het Hof kan het niet nalaten erop te wijzen dat de Portugese Nationale Hoge Raad in 2008 en 2014 in zaken van mannelijke klagers over medische fouten overwoog dat het feit dat de mannen geen normaal seksueel leven meer konden hebben hun eigenwaarde had aangetast en had geresulteerd in een ernstige en vergaande mentale schok, zonder te letten op hun leeftijd of de aanwezigheid van eventuele kinderen. Het Hof concludeert daarom tot 
schending van artikel 8 EVRM in samenhang met artikel 14 EVRM.

\section{Conclusies}

Het Europees Hof voor de Rechten van de Mens heeft gedurende de afgelopen verslagperiode wederom een groot aantal uitspraken gedaan over zaken die voor het gezondheidsrecht van belang zijn. De oogst was minder divers dan afgelopen verslagperiode, maar inhoudelijk heeft het Hof zich over minstens zoveel zaken in duidelijke taal uitgelaten. Dit geldt niet in de minste plaats over het recht op patiëntveiligheid, het optreden van de autoriteiten jegens psychiatrische patiënten, het recht op cannabis en vragen rond levensverlengend handelen in zaken waarin artsen dat niet langer zinvol achten. Maar ook over onderwerpen waarover het Hof zich gedurende de afgelopen jaren eerder heeft uitgelaten, heeft het Hof zijn mening over een aantal zaken verduidelijkt. Het Hof heeft in een aantal zaken verwezen naar het bestaan van een schriftelijke verklaring van 'informed consent'. Of het Hof aan een schriftelijke verklaring meer waarde toekent dan mondelinge toestemming wordt niet duidelijk. Helder is wel dat het voor gezondheidsjuristen van belang blijft de uitspraken van het Hof te volgen, ook vanwege de speciale status van het EVRM in onze rechtsorde. 